Prepared in cooperation with the Virginia Department of Environmental Quality

\title{
Hydrogeologic Framework of the Virginia Eastern Shore
}

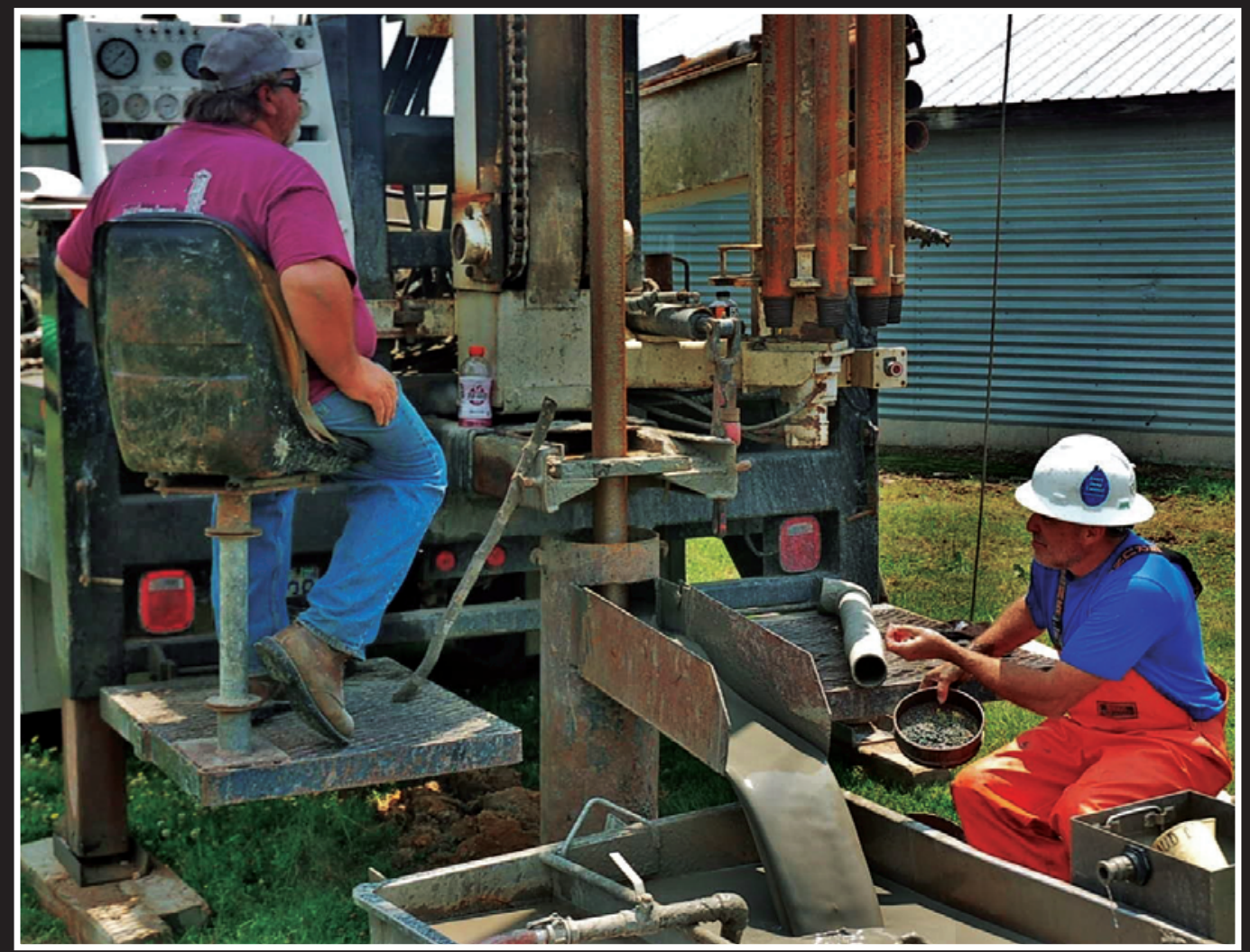

Scientific Investigations Report 2019-5093 
Cover. Processing sediment cuttings from a borehole in Accomack County, Virginia. The hydrogeologic framework of the Virginia Eastern Shore is based on borehole information. Geologic relations among, compositions of, and configurations of aquifers and confining units were determined from geologists' logs of sediment cores and cuttings and from borehole geophysical logs. Hydrogeologic investigation of the Virginia Eastern Shore was undertaken jointly by U.S. Geological Survey (USGS) and Virginia Department of Environmental Quality (VA DEO) as part of the USGS Cooperative Studies Program. Photograph by T. Scott Bruce, VA DEO. 


\section{Hydrogeologic Framework of the Virginia Eastern Shore}

By E. Randolph McFarland and Todd A. Beach

Prepared in cooperation with the Virginia Department of Environmental Quality

Scientific Investigations Report 2019-5093 


\title{
U.S. Department of the Interior DAVID BERNHARDT, Secretary
}

\author{
U.S. Geological Survey \\ James F. Reilly II, Director
}

\section{U.S. Geological Survey, Reston, Virginia: 2019}

For more information on the USGS - the Federal source for science about the Earth, its natural and living resources, natural hazards, and the environment-visit https://www.usgs.gov or call 1-888-ASK-USGS.

For an overview of USGS information products, including maps, imagery, and publications, visit https://store.usgs.gov.

Any use of trade, firm, or product names is for descriptive purposes only and does not imply endorsement by the U.S. Government.

Although this information product, for the most part, is in the public domain, it also may contain copyrighted materials as noted in the text. Permission to reproduce copyrighted items must be secured from the copyright owner.

Suggested citation:

McFarland, E.R., and Beach, T.A., 2019, Hydrogeologic framework of the Virginia Eastern Shore: U.S. Geological Survey Scientific Investigations Report 2019-5093, 26 p., 13 pl., https://doi.org/10.3133/sir20195093.

Associated data for this publication:

McFarland, E.R., 2019, Borehole hydrogeologic-unit top-surface altitudes, aquifer hydraulic properties, and groundwater-sample chloride-concentration data from 1906 through 2016 for the Virginia Eastern Shore: U.S. Geological Survey data release, https://doi.org/10.5066/P9MPE5SD. 


\section{Acknowledgments}

Special thanks for program planning go to Scott W. Kudlas and T. Scott Bruce of the Virginia Department of Environmental Quality (VA DEQ). Thanks also are extended to the many drillers and owners of water-supply wells who provided well data from across the Virginia Eastern Shore, particularly Bundick Well \& Pump Co., Inc., for the majority of geophysical well logs on which interpretations were based.

Valuable scientific contributions to this report were provided from reviews by Alex R. Fiore and Samuel H. Caldwell of the U.S. Geological Survey (USGS). The editorial and graphical quality of the report was aided greatly by Dale L. Simmons and Denis Sun of the USGS.

This project has been funded in part by the U.S. Environmental Protection Agency (EPA) under assistance agreement BG-98392505-1 to the VA DEO. The contents of this document do not necessarily reflect the views and policies of the EPA, nor does the EPA endorse trade names or recommend the use of commercial products mentioned in this document. 


\section{Contents}

Acknowledgments .......................................................................................................................ii

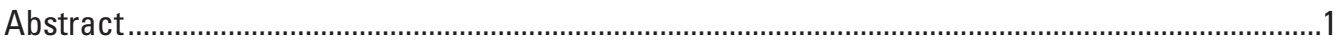

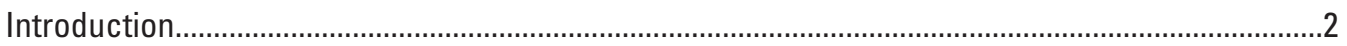

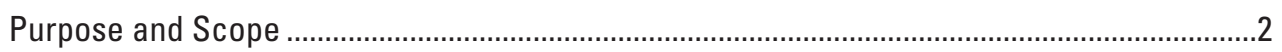

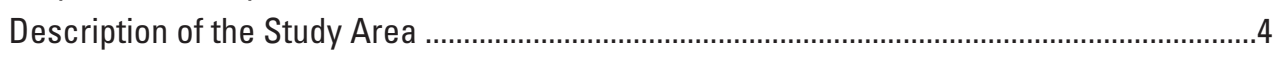

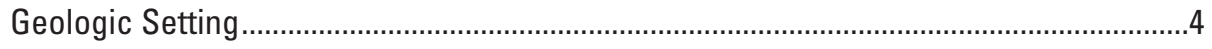

Groundwater Conditions ...............................................................................................

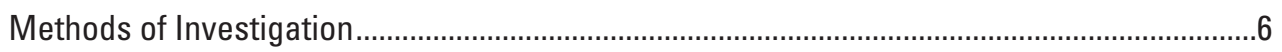

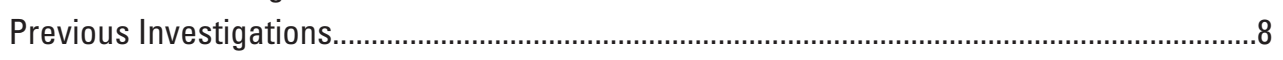

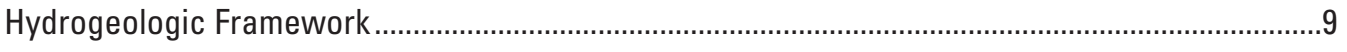

Geologic Relations

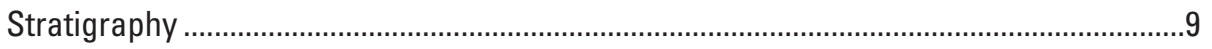

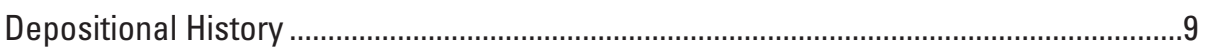

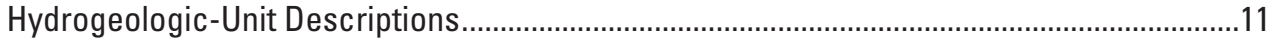

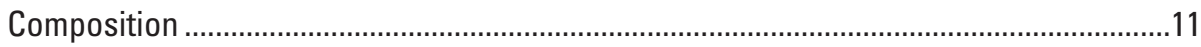

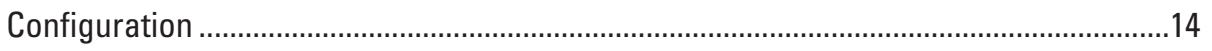

Yorktown-Eastover Aquifer System ...................................................................14

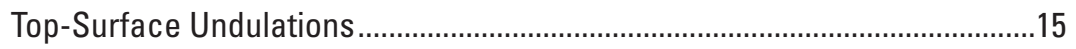

Paleochannel Incision ...............................................................................15

Upper Confining Unit .......................................................................................

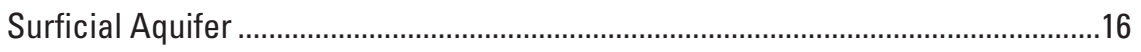

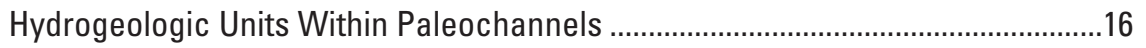

Aquifer Hydraulic Properties ............................................................................................

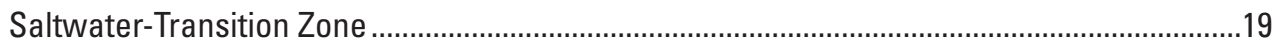

Groundwater Chloride Concentrations .....................................................................19

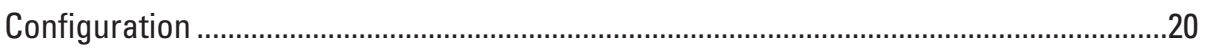

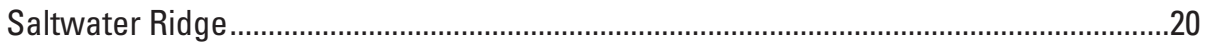

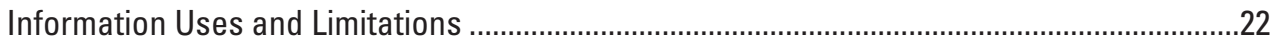

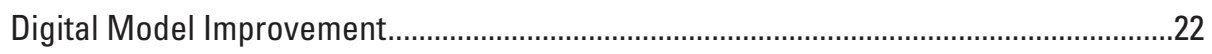

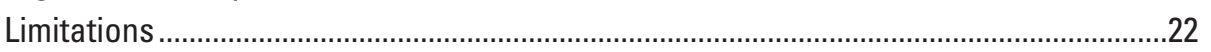

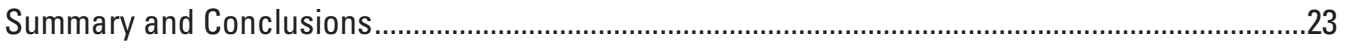

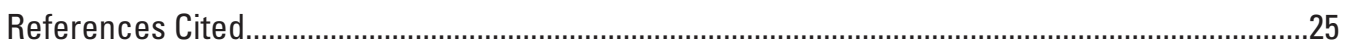

Appendix 1. Hydrogeologic-unit top-surface altitudes in 205 boreholes, Virginia Eastern Shore. available online

Appendix 2. Aquifer hydraulic properties, Virginia Eastern Shore. available online Appendix 3. Chloride concentrations in 2,440 groundwater samples, Virginia Eastern Shore available online 


\section{Plates (in pocket)}

1. Map showing locations and numbers of boreholes on the Virginia Eastern Shore

2. Hydrogeologic section through the Virginia Eastern Shore

3 Map showing top-surface altitude of Saint Marys confining unit on the Virginia Eastern Shore

4 Map showing top-surface altitude of the lower aquifer on the Virginia Eastern Shore

5 Map showing top-surface altitude of the lower confining unit on the Virginia Eastern Shore

6 Map showing top-surface altitude of the middle aquifer on the Virginia Eastern Shore

7 Map showing top-surface altitude of the middle confining unit on the Virginia Eastern Shore

8 Map showing top-surface altitude of the upper aquifer on the Virginia Eastern Shore

9 Map showing top-surface altitude of the paleochannel lower aquifer on the Virginia Eastern Shore

10 Map showing top-surface altitude of the paleochannel confining unit on the Virginia Eastern Shore

11 Map showing top-surface altitude of the paleochannel upper aquifer on the Virginia Eastern Shore

12 Map showing top-surface altitude of the upper confining unit on the Virginia Eastern Shore

13. Map showing locations and numbers of sampled wells and altitude of the 250-milligram-per-liter chloride-concentration surface on the Virginia Eastern Shore

\section{Figures}

1. Map showing locations of boreholes and hydrogeologic section through the Virginia Eastern Shore.

2. Generalized hydrogeologic section, groundwater chloride concentrations, and directions of predevelopment groundwater flow in the Virginia Coastal Plain

3. Maps showing generalized groundwater levels in the Yorktown-Eastover aquifer system on the Virginia Eastern Shore: A, 1900; B, 2000; C, 2016

4. Diagram showing simplified stratigraphic relations among hydrogeologic units and geologic formations of the Virginia Eastern Shore

5. Photographs showing representative sediment lithologies in and geophysical logs from the Eyreville core hole, Northampton County, Virginia

6. Map showing locations and numbers of aquifer-test wells on the Virginia Eastern Shore.

7. Block diagram showing generalized hydrologic relations among aquifers and the Exmore paleochannel on the Virginia Eastern Shore.

\section{Tables}

1. Summary of hydrogeologic-unit top-surface altitudes and thicknesses in 205 boreholes on the Virginia Eastern Shore

2. Summary of estimates of aquifer transmissivity based on results of aquifer tests on 58 wells on the Virginia Eastern Shore... 


\section{Conversion Factors}

U.S. customary units to International System of Units

\begin{tabular}{|c|c|c|}
\hline Multiply & By & To obtain \\
\hline \multicolumn{3}{|c|}{ Length } \\
\hline foot $(\mathrm{ft})$ & 0.3048 & meter $(\mathrm{m})$ \\
\hline mile (mi) & 1.609 & kilometer $(\mathrm{km})$ \\
\hline \multicolumn{3}{|c|}{ Area } \\
\hline square mile $\left(\mathrm{mi}^{2}\right)$ & 259.0 & hectare (ha) \\
\hline square mile $\left(\mathrm{mi}^{2}\right)$ & 2.590 & square kilometer $\left(\mathrm{km}^{2}\right)$ \\
\hline \multicolumn{3}{|c|}{ Volume } \\
\hline gallon (gal) & 3.785 & liter $(\mathrm{L})$ \\
\hline \multicolumn{3}{|c|}{ Flow rate } \\
\hline million gallons per day (Mgal/d) & 0.04381 & cubic meter per second $\left(\mathrm{m}^{3} / \mathrm{s}\right)$ \\
\hline \multicolumn{3}{|c|}{ Transmissivity* } \\
\hline foot squared per day $\left(\mathrm{ft}^{2} / \mathrm{d}\right)$ & 0.09290 & meter squared per day $\left(\mathrm{m}^{2} / \mathrm{d}\right)$ \\
\hline
\end{tabular}

\section{Datum}

Vertical coordinate information is referenced to the National Geodetic Vertical Datum of 1929 (NGVD 29).

Horizontal coordinate information is referenced to the North American Datum of 1927 (NAD 27). Altitude, as used in this report, refers to distance above the vertical datum.

\section{Supplemental Information}

Transmissivity: The standard unit for transmissivity is cubic foot per day per square foot times foot of aquifer thickness [(ft $\left.\left.\mathrm{ft}^{3} / \mathrm{d}\right) / \mathrm{ft}^{2}\right] \mathrm{ft}$. In this report, the mathematically reduced form, foot squared per day $\left(\mathrm{ft}^{2} / \mathrm{d}\right)$, is used for convenience.

Concentrations of chemical constituents in water are given in milligrams per liter (mg/L). 


\section{Abbreviations}

EM electromagnetic induction

EPA U.S. Environmental Protection Agency

NASA National Aeronautics and Space Administration

PVC polyvinyl chloride

SMCL secondary maximum contaminant level

USGS U.S. Geological Survey

VA DEO Virginia Department of Environmental Quality

VA-WV WSC Virginia-West Virginia Water Science Center 


\title{
Hydrogeologic Framework of the Virginia Eastern Shore
}

\author{
By E. Randolph McFarland ${ }^{1}$ and Todd A. Beach ${ }^{2}$
}

\section{Abstract}

The Yorktown-Eastover aquifer system of the Virginia Eastern Shore consists of upper, middle, and lower confined aquifers overlain by correspondingly named confining units and underlain by the Saint Marys confining unit. Miocene- to Pliocene-age marine-shelf sediments observed in 205 boreholes include medium- to coarse-grained sand and shells that compose the aquifers and fine-grained sand, silt, and clay that compose the confining units. The upper confining unit also includes fine-grained and organic-rich back-barrier and estuarine sediments of Pleistocene age. An overlying surficial aquifer is composed mostly of Pleistocene-age nearshore sand and gravel with smaller amounts of cobbles and boulders.

In addition, Pleistocene-age sediments that fill three buried paleochannels are for the first time explicitly delineated here as distinct hydrogeologic units. Two aquifers are composed of medium- to coarse-grained fluvial sand and gravel, and an intervening confining unit is composed of fine-grained estuarine sand, silt, clay, and organic material. Aquifer and confining-unit sediments are also mixed with reworked marine-shelf sediments eroded from the sides of the paleochannels.

Hydrogeologic units of the Yorktown-Eastover aquifer system generally dip eastward, are as much as several tens of feet thick, and have an undulating configuration possibly resulting from the underlying Chesapeake Bay impact crater. Aquifers and confining units are incised by the three paleochannels along an upward-widening and eastwardlengthening series of structural "windows." Hydrogeologic units within mainstems and branching tributaries of the paleochannels dip southeastward parallel to slopes of the paleochannels, are as much as several tens of feet thick, and laterally abut the Yorktown-Eastover aquifer system along paleochannel sidewalls. The Yorktown-Eastover aquifer system is thereby hydraulically breached by the paleochannels to alternately create barriers to or conduits for groundwater flow.

Results of previously documented aquifer tests at 58 wells indicate that transmissivity is generally greatest in

${ }^{1}$ U.S. Geological Survey, Virginia-West Virginia Water Science Center, Richmond, Virginia

${ }^{2}$ Virginia Department of Environmental Quality, Water Resources Management, Richmond, Virginia young, shallow, and coarse-grained nearshore and fluvial sediments of the surficial aquifer and paleochannels. Transmissivity progressively decreases with depth in older, deeper, and finer grained marine-shelf sediments of the Yorktown-Eastover aquifer system, probably because they have undergone compaction as a result of greater overburden pressure over longer periods of time.

Compiled chloride concentrations in samples from 330 wells generally increase downward, with most of the samples collected at altitudes above -300 feet and with most concentrations less than 250 milligrams per liter. The saltwater-transition zone has a broad trough-like shape aligned with the peninsula, being relatively shallow along the coastline and deeper along the central "spine." Because movement of the saltwater is slow, the configuration largely reflects groundwater flow prior to widespread groundwater withdrawals. Fresh groundwater has leaked downward along deep parts of the saltwater-transition zone and leaked upward along shallower parts to discharge at the coast.

The saltwater-transition zone also exhibits an anomalous ridge across the center of the peninsula. Groundwater levels indicate that the saltwater ridge formed primarily by the Exmore paleochannel acting as a large lateral collector drain. Groundwater levels were lowered, and the position of saltwater-transition zone was elevated, by a flow conduit that intercepted groundwater that otherwise would have flowed toward and discharged along the coastline.

Nearly all freshwater on the Virginia Eastern Shore is supplied by groundwater withdrawals, which have lowered water levels, altered hydraulic gradients, and created a concern for saltwater intrusion. Previous characterizations of groundwater conditions that are relied on to manage groundwater development have been limited by a lack of hydrogeologic information, particularly data on buried paleochannels that are critical to safeguarding the groundwater supply. Using recently available expanded information, the U.S. Geological Survey undertook a study in cooperation with the Virginia Department of Environmental Quality during 2016-19 to develop an improved description of the groundwater system called a "hydrogeologic framework."

The hydrogeologic framework can aid water-supply planning and development by providing information on broad trends in aquifer configurations, hydraulic properties, and proximity to saltwater to avoid chloride contamination. Digital models to evaluate effects of groundwater withdrawals can 
also be improved with expanded data and capabilities to evaluate paleochannel hydraulic connections and the potential for saltwater movement.

The hydrogeologic framework is limited by the nonuniform distribution of boreholes and the subjective delineation of aquifers and confining units, including those within paleochannels that are regarded as preliminary. The configuration of the saltwater-transition zone is also regarded as preliminary because of the nonuniform distribution of groundwater samples. Low well-sampling frequency precludes characterizing movement of the saltwater-transition zone. A monitoring strategy of sampling and possibly electromagnetic-induction well logging could be used to detect saltwater movement.

\section{Introduction}

The Atlantic Coastal Plain Physiographic Province (Coastal Plain) extends from Cape Cod, Massachusetts, southward to the Gulf of Mexico. In the eastern part of Virginia, the Coastal Plain occupies an area of approximately 13,000 square miles ( $\left.\mathrm{mi}^{2}\right)$ (fig. 1). Groundwater in the Virginia Coastal Plain is a heavily used resource. The rate of groundwater withdrawal is estimated to have been close to zero during the late $1800 \mathrm{~s}$ but increased during the 20th century. Since 2000, withdrawal rates from Coastal Plain aquifers in Virginia have been maintained at approximately 130 million gallons per day (Mgal/d) (Masterson and others, 2016).

Because withdrawals are large, groundwater levels have declined by as much as 200 feet (ft) near major withdrawal centers, and land-surface subsidence is exacerbating the effects of sea-level rise (Eggleston and Pope, 2013). In addition, flow gradients have steepened and been redirected from seaward to landward, creating the potential for saltwater intrusion. Continuing withdrawal is expected to increase water-level declines, subsidence, and intrusion potential and thereby limit continued use of the resource.

To manage the groundwater resource, the Virginia Department of Environmental Quality (VA DEQ) regulates groundwater withdrawals. Withdrawals within the Virginia Coastal Plain that are greater than 300,000 gallons per month must be approved under the VA DEQ Groundwater Withdrawal Permitting Program (Commonwealth of Virginia, 1992). Groundwater users are required to submit withdrawalrelated information needed to evaluate the potential effects of the withdrawals on aquifers. To provide a valid context within which to make resource-management decisions, the VA DEQ has also maintained a sound scientific understanding of the Virginia Coastal Plain through a cooperative program of hydrogeologic investigation with the U.S. Geological Survey (USGS). A series of studies during the past four decades have advanced the knowledge of diverse aspects of Virginia Coastal Plain geology and hydrology.

The Virginia Eastern Shore is part of the Virginia Coastal Plain (fig. 1) and sound scientific understanding is needed to support effective development and management of its groundwater resource. The Virginia Eastern Shore forms the narrow southernmost part of the Delmarva Peninsula. Because fresh surface water is scarce, nearly all freshwater is supplied by a shallow and laterally constrained groundwater system. As on the mainland part of the Virginia Coastal Plain, increasing groundwater withdrawals have lowered water levels and altered hydraulic gradients, creating a concern for saltwater intrusion from nearby Chesapeake Bay to the west and the Atlantic Ocean to the east.

The VA DEQ and local planners have relied on previous characterizations of the Virginia Eastern Shore groundwater system to manage the resource. Earlier studies were limited, however, by scant borehole information and groundwater chloride-concentration data. Subsequent discovery and investigation of the Chesapeake Bay impact crater (Powars and Bruce, 1999) that underlies part of the peninsula also poses implications for structural alteration of the groundwater system.

Additionally, information on buried paleochannels has been increasingly regarded by the VA DEQ and local planners as critical to safeguarding the groundwater supply. The presence of paleochannels beneath the Virginia Eastern Shore has been generally known for more than 30 years (Mixon, 1985). The paleochannels have a unique configuration and sediment properties that could potentially alter directions and rates of groundwater flow and saltwater movement. Because of data limitations, however, previous studies have only indirectly approximated the possible hydraulic effects of paleochannels.

During approximately the past decade (2009-19) hydrogeologic information on the Virginia Eastern Shore has increased substantially. Particularly, many boreholes have recently been drilled into buried paleochannels. Accordingly, during 2016-19, the USGS undertook an investigation in cooperation with the VA DEQ to improve the characterization of the groundwater system.

\section{Purpose and Scope}

The groundwater system of the Virginia Eastern Shore is characterized here to address information needs for waterresource management. A description of the groundwater system, called a "hydrogeologic framework," is presented. Geologic relations, compositions, and configurations of four aquifers and four confining units that underlie the entire peninsula are described. In addition - and newly designated here- two aquifers and one confining unit that are restricted to three buried paleochannels are described. This characterization is the first explicit delineation of sediments that fill the paleochannels as distinct hydrogeologic units.

Aquifers and confining units are illustrated by means of borehole geophysical logs, photographs of sediment lithologies, structural contour maps, and a hydrogeologic section. Structural features of the aquifers and confining units, and their hydraulic connectivity along paleochannels, are also described.

Additionally, previously documented estimates of aquifer transmissivity and storativity are presented and compared 


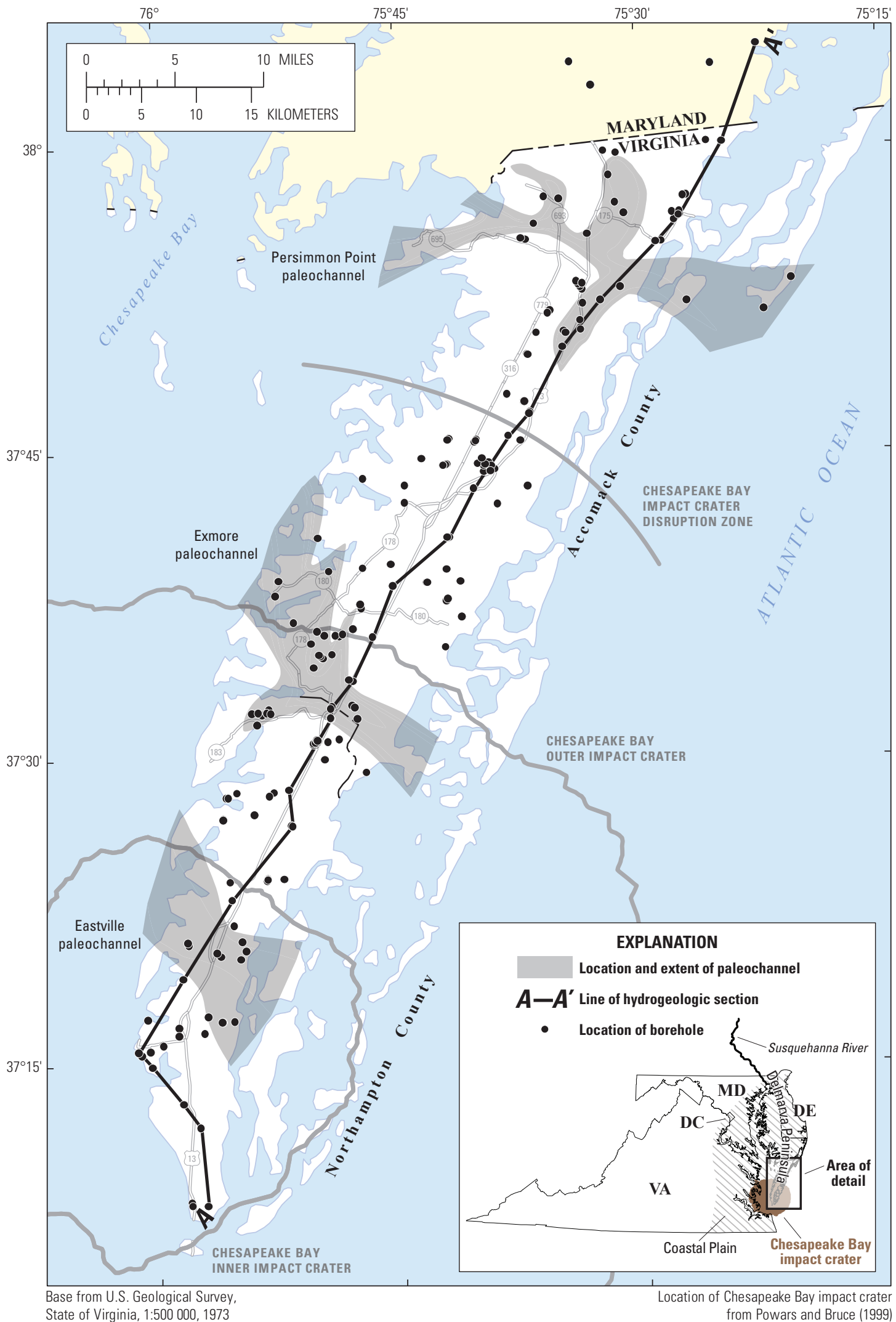

Figure 1. Locations of boreholes and hydrogeologic section through the Virginia Eastern Shore. Additional details are shown on plate 1; hydrogeologic section shown on plate 2 . 
among the aquifers. Groundwater chloride concentrations are presented, and their distribution is analyzed to delineate the freshwater-saltwater transition zone. Lastly, possible uses and limitations of the above information for water-resource management are discussed.

\section{Description of the Study Area}

The Virginia Eastern Shore is the part of the Coastal Plain in Virginia that is separated from the mainland by Chesapeake Bay to form the southernmost part of the Delmarva Peninsula (fig. 1). The Virginia part of the peninsula extends approximately 70 miles (mi) from the State line to its terminus at the mouth of Chesapeake Bay. To the north in Maryland, the Delmarva Peninsula is as much as approximately $70 \mathrm{mi}$ wide, but southward into Virginia it narrows abruptly to a width of approximately $15 \mathrm{mi}$ or less.

Much of the eastern third to half of the Virginia Eastern Shore forms a complex of low barrier islands and broad tidal lagoons adjacent to the Atlantic Ocean (fig. 1, pl. 1). In contrast, the central and western parts of the peninsula have land-surface altitudes as high as $50 \mathrm{ft}$ and are relatively well drained. Several small streams in this area represent the only fresh surface water. These flow from the highest altitude "spine" along the axis of the peninsula either eastward into the barrier-lagoon complex or westward into a series of tidal bays along the shore of Chesapeake Bay.

Local jurisdiction of the Virginia Eastern Shore is divided between the counties of Accomack to the north and Northampton to the south (fig. 1, pl. 1). Much of the eastern barrier-lagoon complex in both counties is uninhabited and under conservation. Higher altitude areas to the west are rural and have a low-density population. Primarily agricultural land use includes production of corn, soybeans, poultry, and timber. Fruit and vegetable production is also active but less widespread than in previous years. Population centers are limited to several small towns arrayed along Route 13 (pl. 1), which generally follows the spine of the peninsula. Several resort developments and other small residential "crossroad" communities are more distant from the spine. The only large industrial operations are two poultry-processing facilities located in north-central Accomack County. Concentrated activity is also conducted at the National Aeronautics and Space Administration (NASA) Wallops Flight Facility located in northeastern Accomack County (fig. 1). The tourism venue of Chincoteague, on the Atlantic Coast in far northeastern Accomack County, is the only developed part of the barrierlagoon complex. Tourism is also being developed at Cape Charles on the shore of Chesapeake Bay in far southwestern Northampton County.

\section{Geologic Setting}

The Coastal Plain is underlain by a seaward-thickening wedge of unconsolidated to partly consolidated sediments overlying a bedrock basement (fig. 2). Regionally extensive, generally eastward-dipping strata are of Cretaceous, Paleogene, Neogene, and Quaternary age (Mixon and others, 1989). Igneous and metamorphic rocks of late Proterozoic and early Paleozoic age, along with sedimentary and igneous rocks of Triassic and Jurassic age, are near land surface to the west but dip eastward to unconformably underlie Coastal Plain sediments.

The sediment wedge extends from Cape Cod, Massachusetts, southward to the Gulf of Mexico and offshore beneath the Continental Shelf. Sediment thickness in Virginia ranges from near $0 \mathrm{ft}$ at its western margin to more than $6,000 \mathrm{ft}$ along the Atlantic Coast. The sediments were deposited by seaward progradation of fluvial plains and deltas along the North American continental margin, followed by a series of transgressions and regressions by the Atlantic Ocean in response to changes in sea level. Fluvial strata primarily of Cretaceous age are overlain by marine strata of Paleogene and Neogene age, which are overlain in turn by terrace and floodplain deposits primarily of Quaternary age.

Coastal Plain sediments in Virginia were affected during the Eocene Epoch by the impact of an asteroid or comet near the mouth of the present-day Chesapeake Bay (Powars and Bruce, 1999). The buried Chesapeake Bay impact crater is greater than $50 \mathrm{mi}$ in diameter and extends across a large part of the southeastern Virginia Coastal Plain, including the southern half of the Virginia Eastern Shore (figs. 1 and 2, pls. 1 and 2). The crater formed within preexisting sediments and contains unique impact-related materials as deep as basement bedrock. Subsequent deposition has buried craterfill sediments approximately $1,000 \mathrm{ft}$ below the present-day land surface.

The Virginia Eastern Shore is the geologically youngest part of the Virginia Coastal Plain. The widest part of the Delmarva Peninsula in Maryland and Delaware is composed of Pliocene- and Pleistocene-age fluvial and deltaic sediments overlying Pliocene- and Miocene-age marine-shelf sediments (Oertel and Foyle, 1995; Hobbs, 2004). To the south, the Virginia part of the peninsula is a relatively narrow spit formed by longshore currents. Mostly Pleistocene-age near-shore and back-barrier sediments overlie Pliocene-age marine-shelf sediments. In addition, Pleistocene-age fluvial and estuarine sediments are contained within paleochannels that are incised as much as $200 \mathrm{ft}$ into Pliocene- and Miocene-age marine-shelf sediments and are buried by overlying spit sediments.

\section{Groundwater Conditions}

Virginia Coastal Plain sediments form a stratigraphic series of hydrogeologic units (fig. 2) (McFarland and Bruce, 2006). Groundwater is present in pores between sediment grains. Permeable sediments through which most groundwater flows are designated as aquifers, and less permeable sediments that restrict flow are designated as confining units or zones. Precipitation that infiltrates the land surface and percolates to the water table either flows relatively short distances and discharges to nearby streams or leaks downward to recharge deeper, confined aquifers. 


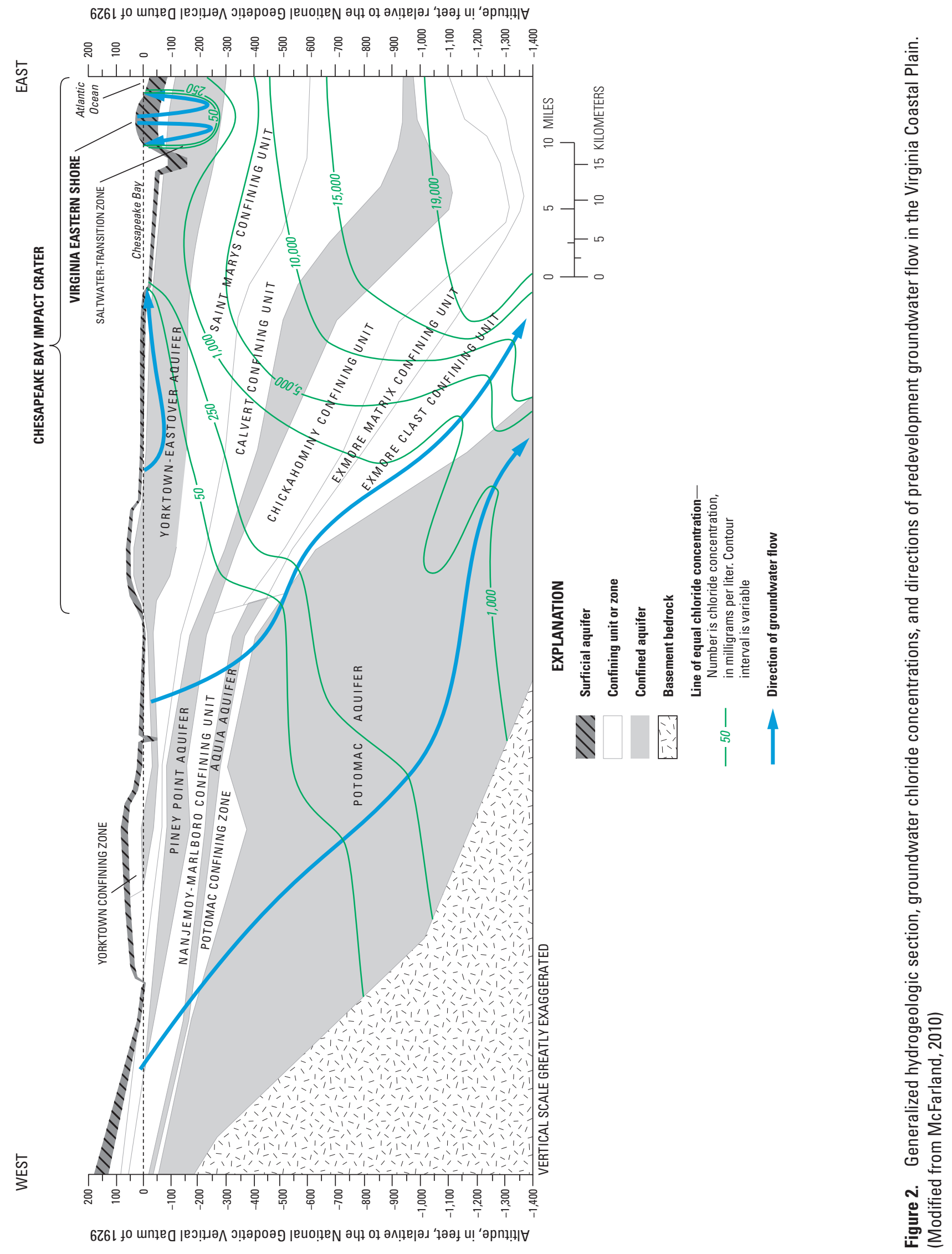


Prior to present-day large withdrawals, groundwater flowed primarily eastward through confined aquifers (fig. 2) and leaked upward to discharge to major rivers, Chesapeake Bay, and the Atlantic Ocean. Groundwater withdrawals have increased over the past century to as much as approximately $130 \mathrm{Mgal} / \mathrm{d}$ (Masterson and others, 2016). Consequently, groundwater levels have declined by as much as $200 \mathrm{ft}$ in parts of the Virginia Coastal Plain and have induced sediment compaction and land subsidence (Eggleston and Pope, 2013). In addition, flow that is now redirected landward toward withdrawal centers creates the potential for long-term lateral saltwater intrusion (McFarland, 2015).

The Virginia Eastern Shore occupies a relatively small and shallow part of the easternmost Virginia Coastal Plain (fig. 2). Although thick and deep sediments underlie the Virginia Eastern Shore, they contain dense stagnant saltwater that is mounded over the Chesapeake Bay impact crater (McFarland, 2010). Fresh groundwater is present to depths generally less than $300 \mathrm{ft}$. As on the mainland Virginia Coastal Plain, precipitation on the Virginia Eastern Shore percolates to the water table. Groundwater either flows short distances to discharge to the land surface or leaks downward to recharge confined aquifers. Discharge from confined aquifers is primarily by upward leakage to Chesapeake Bay and the Atlantic Ocean (Sanford and others, 2009).

Prior to widespread groundwater withdrawals on the Virginia Eastern Shore, estimated groundwater-level altitudes were below $5 \mathrm{ft}$ near the coastline but higher than $5 \mathrm{ft}$ across the entire interior of the peninsula (fig. $3 A$ ). Relatively low water levels (between 5 and $10 \mathrm{ft}$ ) spanned the interior in northern Northampton County and southern Accomack County. Across much of the rest of both counties, water levels were higher- $30 \mathrm{ft}$ or more along parts of the central spine. A divide thereby existed between westward flow toward Chesapeake Bay and eastward flow toward the Atlantic Ocean.

Groundwater withdrawals on the Virginia Eastern Shore were less than approximately $0.5 \mathrm{Mgal} / \mathrm{d}$ prior to the mid1960s but increased to approximately $5 \mathrm{Mgal} / \mathrm{d}$ during the 1970s and into the 21st century (Sanford and others, 2009). Consequently, groundwater levels declined across most of the peninsula. By 2000, groundwater-level altitudes were below $5 \mathrm{ft}$ across most of Accomack County and northernmost Northampton County (fig. $3 B$ ). In addition, water levels within two cones of depression in Accomack County were below sea level. As a result, the hydraulic gradient was locally redirected landward to create the potential for saltwater intrusion. During 2016, most observed groundwater-level altitudes were below $5 \mathrm{ft}$ (fig. $3 \mathrm{C}$ ). In addition, the locations, magnitudes, and extents of cones of depression in Accomack County had changed since 2000 .

\section{Methods of Investigation}

During 2016-19, geologic relations, compositions, and configurations of six aquifers and five confining units that compose the groundwater system of the Virginia Eastern Shore were determined. Geophysical logs, geologists' logs of sediment core and drill-cutting lithologies, and other ancillary data from 205 boreholes were analyzed (fig. 1, pl. 1). (The map showing borehole locations [pl. 1] is scaled to fit on 11by 17 -inch paper so that the digital version can be printed on standard office equipment.)

For this study, data were collected by the VA DEQ from 125 newly drilled boreholes. Records for these and an additional 63 boreholes are on file at the USGS Virginia-West Virginia Water Science Center (VA-WV WSC) in Richmond, Virginia. Geophysical logs from 186 of these boreholes located in Virginia can also be accessed from the USGS log-archive website https://webapps.usgs.gov/GeoLogLocator/\#!/search (where well numbers used in this report can be searched as "station name"). Additional published data include sediment lithologic descriptions from 13 boreholes located on the Virginia part of the peninsula (Mixon, 1985) and geophysical logs of 4 boreholes located within $5 \mathrm{mi}$ to the north in Maryland (Andreasen and others, 2013).

Hydrogeologic-unit top-surface altitudes were determined at each borehole (app. 1; McFarland, 2019). Geophysical logs and other borehole data were interpreted to distinguish geologic relations and determine compositions of and configurations among aquifers and confining units. Stratigraphic correlation of the aquifers and confining units among boreholes was supported by construction of a hydrogeologic section positioned approximately along the central spine of the peninsula (fig. 1, pl. 2). The hydrogeologic section is aligned to intercept 23 boreholes having the highest quality data, including geologists' logs of sediment core and drill-cutting lithologies. The aquifers and confining units were further delineated by construction of 10 structural contour maps that represent the altitudes and configurations of their top surfaces (pls. 3-12). Structure contours were digitized by hand to approximately interpolate top-surface altitudes between boreholes. (These hydrogeologic-section and structural-contour map plates are scaled to fit on 11- by 17-inch paper so that digital versions can be printed on standard office equipment.)

Estimates of aquifer hydraulic properties were compiled from records on file with the VA DEQ. Internal reports by agency staff that evaluate groundwater-withdrawal permit applications include results of aquifer tests performed on 58 wells. The results include 133 estimates of aquifer transmissivity, 85 estimates of storativity, and 18 estimates of specific yield (app. 2; McFarland, 2019). Estimates of transmissivity were summarized to compare among the aquifers.

Chloride concentrations were compiled for 2,440 groundwater samples collected during 1906-2016 from 330 wells on the Virginia Eastern Shore (pl. 13). Chloride-concentration data were obtained from multiple sources (app. 3; McFarland, 2019). Concentrations in 289 samples were retrieved from the USGS National Water Information System database (U.S. Geological Survey, 2017). Analyses for an additional 1,419 samples were obtained from the VA Hydro database of 

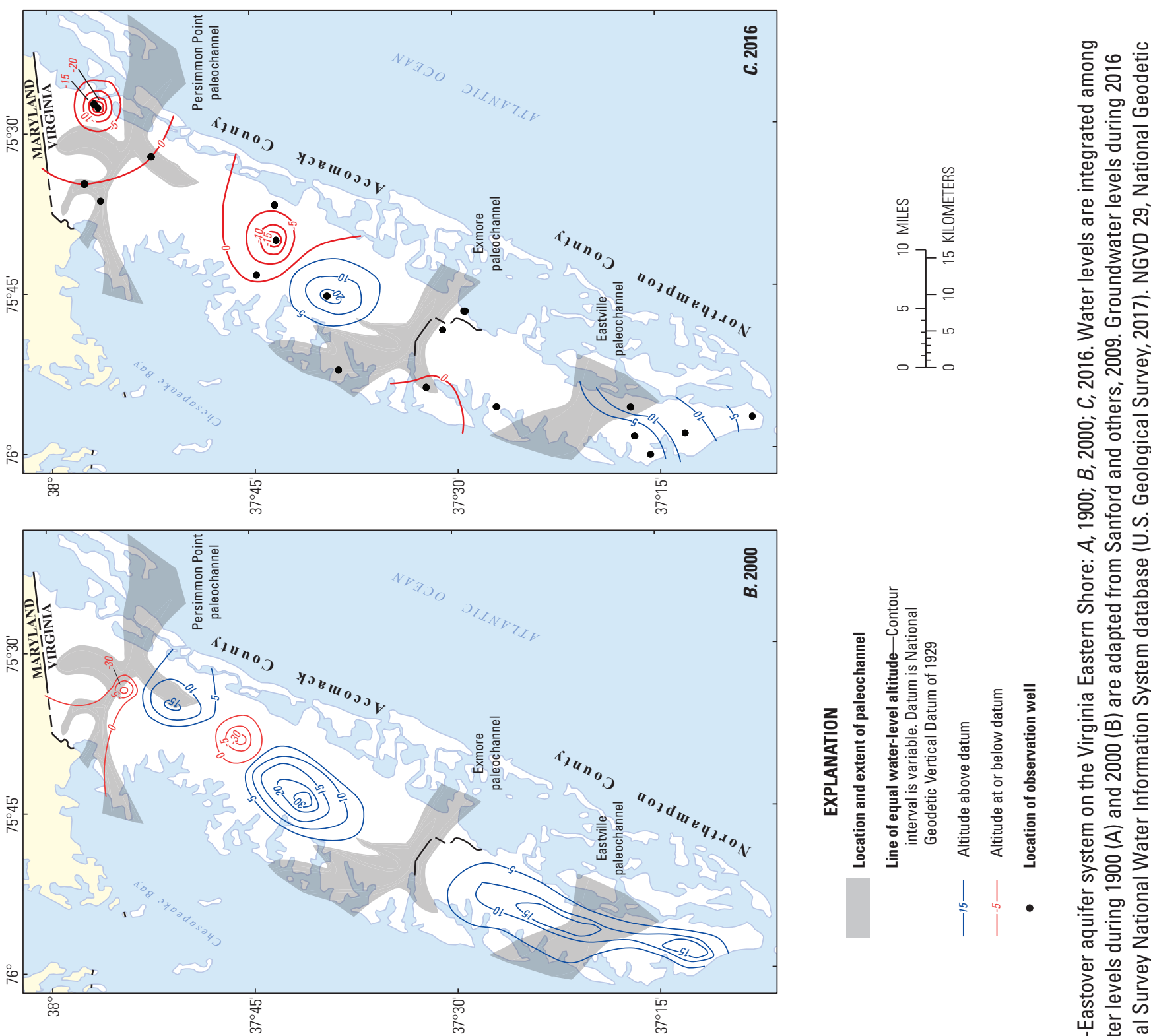

एक

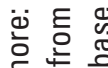

क क त

음 is 完

ш

들

잉

๑ 율

등

产这

잉

के

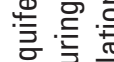

匹

के ल बे

额
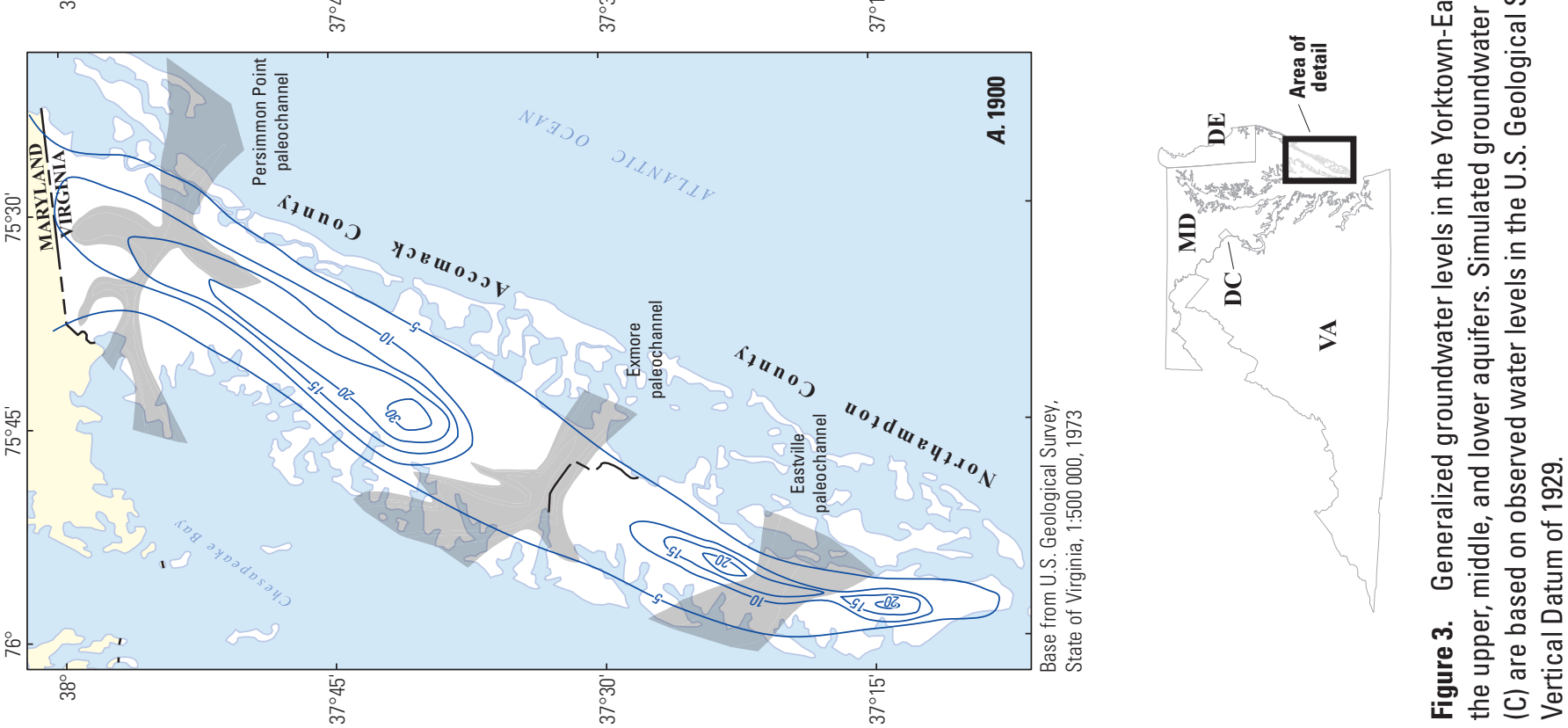
the VA DEQ. Published data include those for 661 samples (McFarland, 2010) and 71 samples (Fennema and Newton, 1982). Chloride concentrations in wells that were sampled multiple times were in some cases obtained from more than one data source.

Ion charge balance was used to quality-assure the chloride concentrations. For samples that were analyzed for all major ions, chloride concentrations were retained only for charge balance values within plus or minus 5 percent. For other samples that were not analyzed for all major ions, chloride concentrations were also retained but were identified as not having charge balance values calculated.

The distribution of groundwater chloride concentrations was analyzed to delineate the freshwater-saltwater transition zone beneath the Virginia Eastern Shore. Concentrations in samples from wells near the hydrogeologic section were transposed onto the section (pl. 2). From these, chloride-concentration contours of 250 milligrams per liter $(\mathrm{mg} / \mathrm{L})$ - the secondary maximum contaminant level for chloride (U.S. Environmental Protection Agency, 1990) - and of 1,000 mg/L were plotted on the section. Subsequently, all chloride concentrations were used to areally delineate altitude contours that approximate the configuration of the $250-\mathrm{mg} / \mathrm{L}$ concentration surface beneath the entire peninsula (pl. 13). Chloride-surface contours were digitized by hand to approximately interpolate the surface altitude between well samples. (The chloridesurface map plate [pl. 13] is scaled to fit on 11- by 17-inch paper so that the digital version can be printed on standard office equipment.)

\section{Previous Investigations}

For more than a century, many publications have documented various aspects of groundwater in parts of or the entire Virginia Coastal Plain. Some of these works included the Virginia Eastern Shore at varying levels of detail. A relatively complete historical summary of hydrogeologic studies is provided by McFarland and Bruce (2006), and studies of groundwater chemical composition are summarized by McFarland (2010).

Early pioneering studies that focused solely on the Virginia Eastern Shore were done by Sinnott and Tibbitts (1954, 1955, 1957, and 1968). Cushing and others (1973) then undertook a comprehensive study of water resources of the entire Delmarva Peninsula. More emphasis was placed on Maryland and Delaware than on Virginia, however, and more on surface water than on groundwater. Subsequently, a series of studies by the Commonwealth of Virginia $(1975,1977$, 1978 ) addressed various aspects of groundwater specifically on the Virginia Eastern Shore. Also, the first numerical simulation of groundwater flow on the Virginia Eastern Shore was done during this period (Bal, 1977). These studies provided only generalized descriptions of aquifers, however, and did not develop a comprehensive hydrogeologic framework.
Fennema and Newton (1982) published the first explicit delineation of aquifers and confining units across the Virginia Eastern Shore. On the basis of stratigraphic correlation among borehole geophysical logs, a surficial unconfined aquifer is continuously underlain by three confined aquifers, which are wholly separated by intervening confining units. Although at the time the deeper sediments were thought to be entirely of Miocene age, the surficial sediments were determined to be of Pleistocene age. No further rationale was developed, however, as a basis for geologic relations among the aquifers and confining units. Major-ion concentrations in groundwater samples were also presented, and an altitude-contour map of the 250-mg/L chloride-concentration surface beneath the Virginia Eastern Shore was constructed. No representation was made of either the Chesapeake Bay impact crater or buried paleochannels, both of which were unknown at that time.

Two digital models of the Virginia Eastern Shore groundwater system were subsequently constructed. A model developed by Richardson (1994) was used to simulate groundwater levels and flow, as well as simplified movement of the freshwater-saltwater transition zone as a sharp (nondiffusive) interface. Sanford and others (2009) developed another model of groundwater levels, flow, and solute transport that more realistically simulates movement of a diffusive freshwatersaltwater transition zone as changes in groundwater chloride concentration. Both models adapted the hydrogeologic framework of Fennema and Newton (1982) on the basis of geologic relations for the entire Virginia Coastal Plain established by Meng and Harsh (1988). Neither model directly represents buried paleochannels distinctly as delineated aquifers. Instead, possible hydraulic effects of the paleochannels are approximated indirectly by varying assumed values of sediment hydraulic properties assigned to parts of some confined-aquifer model layers. Both models have been used by the VA DEQ to evaluate effects of groundwater withdrawals on the Virginia Eastern Shore.

In addition to hydrogeologic studies, geologic relations of sediments that compose the Virginia Eastern Shore aquifer system have been analyzed. Deep sediments that compose confined aquifers and confining units have been studied in detail, but mostly in individual core holes (Powars and Bruce, 1999; Browning and others, 2009; Edwards and others, 2009). Shallower sediments (mostly within $100 \mathrm{ft}$ of land surface) that primarily constitute the surficial aquifer have been more broadly characterized. A comprehensive analysis by Mixon (1985) represents a major benchmark, including delineation of two buried paleochannels by means of mapping altitude contours of the Quaternary-age erosion surface. Subsequently, Oertel and Foyle (1995), Nowroozi and others (2003), Hobbs (2004), Powars (2011), Krantz and others (2016), and Powars and others (2016) further theorized the number and alignments of paleochannels. The role of paleochannels in the sediment depositional history and geomorphic development of the Virginia Eastern Shore remains a topic of active research. 


\section{Hydrogeologic Framework}

The Virginia Eastern Shore, the easternmost part of the Virginia Coastal Plain, is underlain by a layered series of hydrogeologic units. Fresh groundwater occupies only a small part of shallow sediments (fig. 2) that have previously been designated regionally as the surficial aquifer, Yorktown confining zone, and Yorktown-Eastover aquifer (McFarland, 2010). In contrast, other studies that focused solely on the Virginia Eastern Shore described an unconfined surficial aquifer and three confined aquifers separated by intervening confining units (Fennema and Newton, 1982; Richardson, 1994; Sanford and others, 2009). The latter description is largely maintained here. The "Yorktown-Eastover aquifer system" is designated to include separate upper, middle, and lower confined aquifers that are each overlain by correspondingly named confining units (fig. 4). The Yorktown-Eastover aquifer system is overlain by the surficial aquifer and underlain by the Saint Marys confining unit, which is contiguous with the regional Virginia Coastal Plain groundwater system.

In addition - and newly designated here - upper and lower confined aquifers are separated by a confining unit within buried paleochannels (fig. 4). This characterization is the first explicit delineation of sediments that fill the paleochannels as distinct hydrogeologic units. The paleochannel aquifers and confining unit are considered separate from the Yorktown-Eastover aquifer system and the surficial aquifer.

\section{Geologic Relations}

In addition to hydrogeologic units, sediments underlying the Virginia Eastern Shore have been designated among a series of geologic formations (fig. 4) on the basis of their ages and depositional history. Relations between the geologic formations and corresponding hydrogeologic units are important to understanding their compositions and configurations.

\section{Stratigraphy}

Sediments that compose the hydrogeologic units were deposited primarily during the Miocene, Pliocene, and Pleistocene Epochs from approximately 20,000 to 11 million years ago (Edwards and others, 2009). Progressing stratigraphically upward, the Saint Marys Formation and overlying Eastover Formation are composed of marine-shelf sediments of Miocene age (fig. 4). These constitute the Saint Marys confining unit and the lower to middle parts of the Yorktown-Eastover aquifer system (partly to entirely through the middle confining unit, depending on location).

The Yorktown Formation is composed of marine-shelf sediments of Pliocene age (fig. 4) and constitutes most of the rest of the Yorktown-Eastover aquifer system (partly to entirely through the upper confining unit, depending on location). In addition, Pliocene-age marine-shelf sediments of the Chowan River Formation at some locations are fine grained and compose part of the upper confining unit, and at other locations are coarse grained and compose part of the surficial aquifer.

The Omar Formation (Accomack Member), Nassawadox Formation (Occohannock, Butlers Bluff, and Stumptown Members), and the Joynes Neck Sand, Wachapreague, and Kent Island Formations are of Pleistocene age (fig. 4). Parts of some of these formations are composed of fine-grained and organic-rich back-barrier and estuarine sediments that are included at some locations in the upper confining unit. The formations are more widely composed of nearshore sediments, however, which are coarser grained and constitute the surficial aquifer.

Pleistocene-age sediments also compose the upper and lower confined aquifers and intervening confining unit within buried paleochannels (fig. 4). Only the Stumptown Member of the Nassawadox Formation has been formally recognized among these sediments (Mixon, 1985), and only within one of the paleochannels. The Stumptown Member is subdivided into a coarse-grained fluvial Unit A, which constitutes the paleochannel lower aquifer, and overlying fine-grained estuarine Unit B and Unit C, which constitute the paleochannel confining unit. Coarse-grained fluvial sediments that compose the paleochannel upper aquifer have not been formally recognized as a geologic formation.

\section{Depositional History}

Deposition of sediments that compose the hydrogeologic units was controlled by fluctuations in Earth-surface temperature and sea level. The Delmarva Peninsula had not yet formed during the Miocene and Pliocene Epochs from 2 to 11 million years ago. Earth-surface temperature was greater than at the present day, and most of the Virginia Coastal Plain was inundated by open ocean in which marine-shelf sediments of the Saint Marys, Eastover, Yorktown, and Chowan River Formations were widely deposited (Ward and Strickland, 1985). These sediments varied in composition at different stages of basin development. The Susquehanna River and other major rivers that now flow to the Chesapeake Bay instead discharged directly to the Atlantic Ocean because the bay had not yet been formed.

Temperature decreased during the late Pliocene Epoch into the early Pleistocene Epoch. Large quantities of coarsegrained glacial outwash were deposited from the Susquehanna River and farther north as a prograding complex of floodplains and deltas (Oertel and Foyle, 1995; Hobbs, 2004). These sediments largely form the part of the Delmarva Peninsula now in Maryland and Delaware (fig. 1). Subsequently, the Susquehanna River and other major rivers were regionally redirected southward, possibly because of ongoing sediment compaction and subsidence centered on the Chesapeake Bay impact crater (Powars and Bruce, 1999).

During the middle Pleistocene Epoch from 1 million to 20,000 years ago, temperature repeatedly fluctuated between several degrees above and below that of present day. Some 


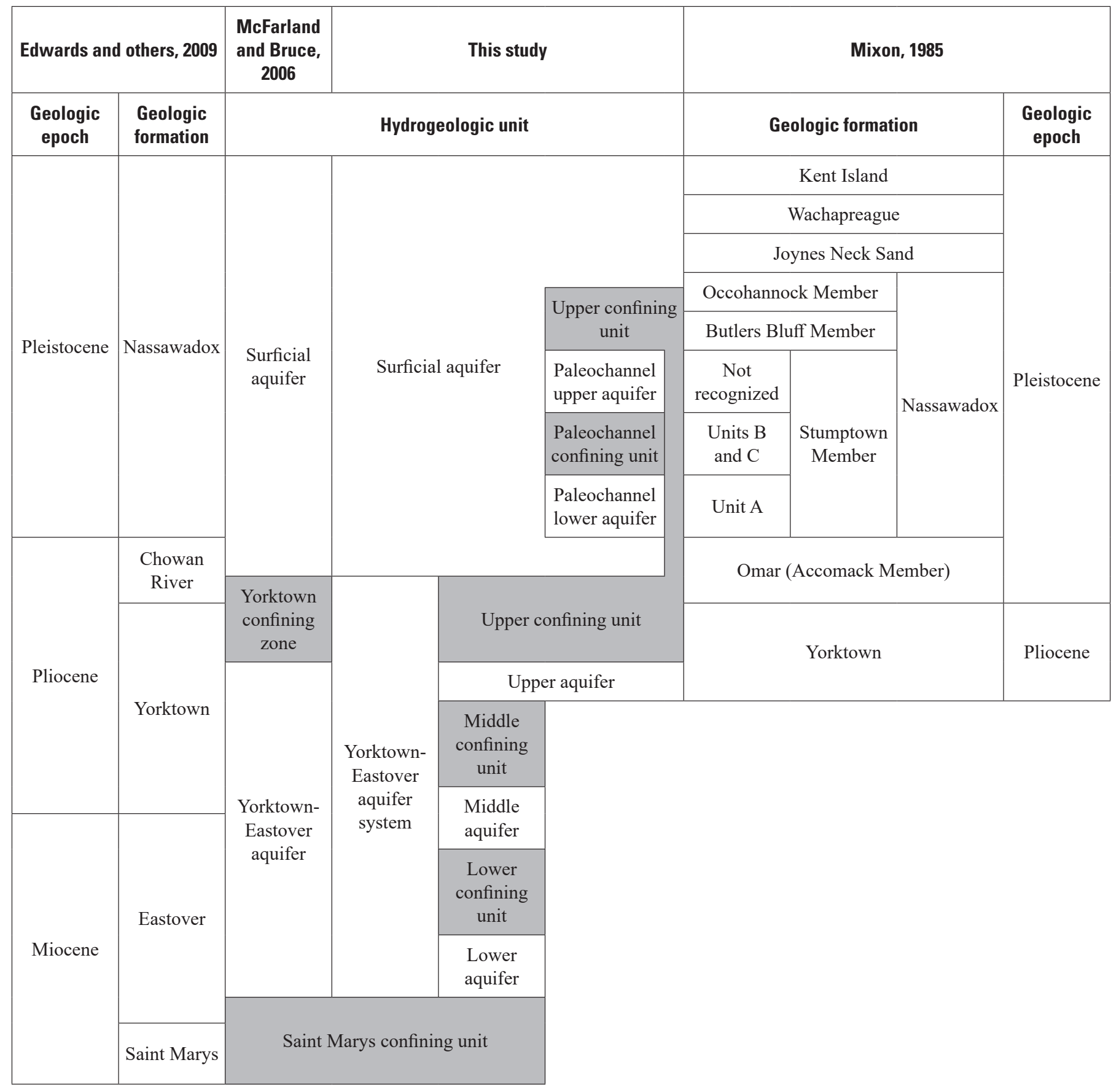

Figure 4. Simplified stratigraphic relations among hydrogeologic units and geologic formations of the Virginia Eastern Shore. 
high sea-level stands exceeded those of present day, whereas low stands resulted in the coast being positioned as far east as the Continental Slope. During high stands, the Delmarva Peninsula was extended to form the Virginia Eastern Shore (Oertel and Foyle, 1995; Hobbs, 2004). Sediment was eroded by south-flowing longshore currents along the Atlantic Coast and redeposited as a narrow elongating spit.

During low sea-level stands, most of the Continental Shelf emerged as a large plain. East-flowing freshwater rivers incised channels tens of feet deep into exposed Miocene- to Pliocene-age marine-shelf sediments, including those beneath the present-day Virginia Eastern Shore. The bottoms of actively incising channels were lined with coarse-grained fluvial sediments along relatively narrow low-lying floodplains and terraces. Subsequently, during sea-level rise and inundation, the channels flooded to become brackish-water estuaries and were backfilled with fine-grained and organicrich sediment. Both fluvial and estuarine sediments were also mixed with reworked marine-shelf sediments eroded from the sides of the channels during incision. Analogous conditions currently exist along estuarine segments of the major rivers on the mainland part of the Virginia Coastal Plain.

Periods of high-stand spit building alternated with lowstand channel incision. The spit was elongated incrementally with each high stand. During each low stand and emergence of the Continental Shelf, a new drainage pattern among the major rivers was diverted around the spit and positioned farther south than previously. A southward sequence of channel realignments and stream captures thereby took place, with successive backfilling and burial of abandoned channel segments to the north. Since the late Pleistocene Epoch, sea level has risen continuously to inundate and backfill the most recently cut channels beneath the newly formed Chesapeake Bay.

\section{Hydrogeologic-Unit Descriptions}

As on the mainland part of the Virginia Coastal Plain, groundwater beneath the Virginia Eastern Shore is present in pores between sediment grains. Permeable, coarse-grained sediments through which most groundwater flows are designated as aquifers, and less permeable, fine-grained sediments that restrict flow are designated as confining units.

\section{Composition}

The Saint Marys confining unit and most of the Yorktown-Eastover aquifer system are composed of marine-shelf sediments. Alternate designations of these sediments as either aquifers or confining units are based on relative differences in texture. Most of the sediments, however, are mixtures spanning a range of grain sizes. A continuum thereby exists among the coarser grained sediments designated as aquifers and the finer grained sediments designated as confining units.

The upper, middle, and lower aquifers are composed predominantly of medium- to coarse-grained sand with variable amounts of shell (fig. 5). Sand grains are composed mostly of quartz but in places also include smaller amounts of glauconite, phosphate, mica, and other minerals. The most coarse-grained and permeable parts of the aquifers contain substantial proportions of shell. The shells represent a large diversity of marine fauna. One species of practical importance is the distinctly pearly lustered mollusk Isognomon maxillata. This shell can be used to distinguish between sediments of the Eastover Formation, where it is present, from those of the overlying Yorktown Formation, where it is absent. Moreover, fragments of the shell are relatively easily identifiable in sediment core and drill cuttings. The presence of Isognomon maxillata is thereby diagnostic of the middle and lower aquifers, whereas its absence indicates the upper aquifer.

The Saint Marys confining unit and the confining units within the Yorktown-Eastover aquifer system are also composed mostly of marine-shelf sediments. In contrast to the aquifers, however, the confining units consist predominantly of fine-grained sand, silt, and clay (fig. 5). Shell material is less abundant than in the aquifers. Parts of the upper confining unit also include sediments of Pleistocene age (fig. 4) that are fine grained and organic rich, and were deposited in back-barrier and estuarine environments. Parts of some confining units contain mostly fine-grained sand that allows vertical leakage of groundwater between adjacent aquifers, whereas other parts contain mostly silt and clay that more effectively restrict vertical leakage and confine groundwater between aquifers.

In contrast to the marine-shelf sediments of the Yorktown-Eastover aquifer system, the surficial aquifer is composed mostly of nearshore sediments. These consist predominantly of quartz sand but also include heavy minerals (Mixon, 1985 ) and are generally coarser grained than the marine-shelf sediments. Some parts of the surficial aquifer also include quartzite, chert, and other lithic gravel (fig. 5) and cobbles and boulders greater than $1 \mathrm{ft}$ in diameter (Curtis Consolvo, Georesources, Inc., written commun., 2018). These materials likely originated as fluvial sediments in buried paleochannels that were later reworked during nearshore deposition of the surficial aquifer. Shell is generally less concentrated in the surficial aquifer than in the Yorktown-Eastover aquifer system, except where the surficial aquifer includes sediments of the Chowan River Formation (fig. 4), which are coarse grained and were deposited in a marine-shelf environment.

Hydrogeologic units within buried paleochannels are composed of fluvial and estuarine sediments that are mixed with reworked marine-shelf sediments. The lower aquifer and upper aquifer consist of fluvial medium- to coarse-grained sand and gravel. Quartzite and other lithic cobbles and boulders are also present at some locations. The intervening confining unit consists of estuarine fine-grained sand, silt, and clay along with substantial proportions of organic material in the form of plant fragments and peat.

The paleochannel aquifers and confining unit also include marine-shelf sediments that were eroded from the sides of the paleochannels during incision. Marine-shelf sediments were subsequently reworked as the paleochannels were flooded 


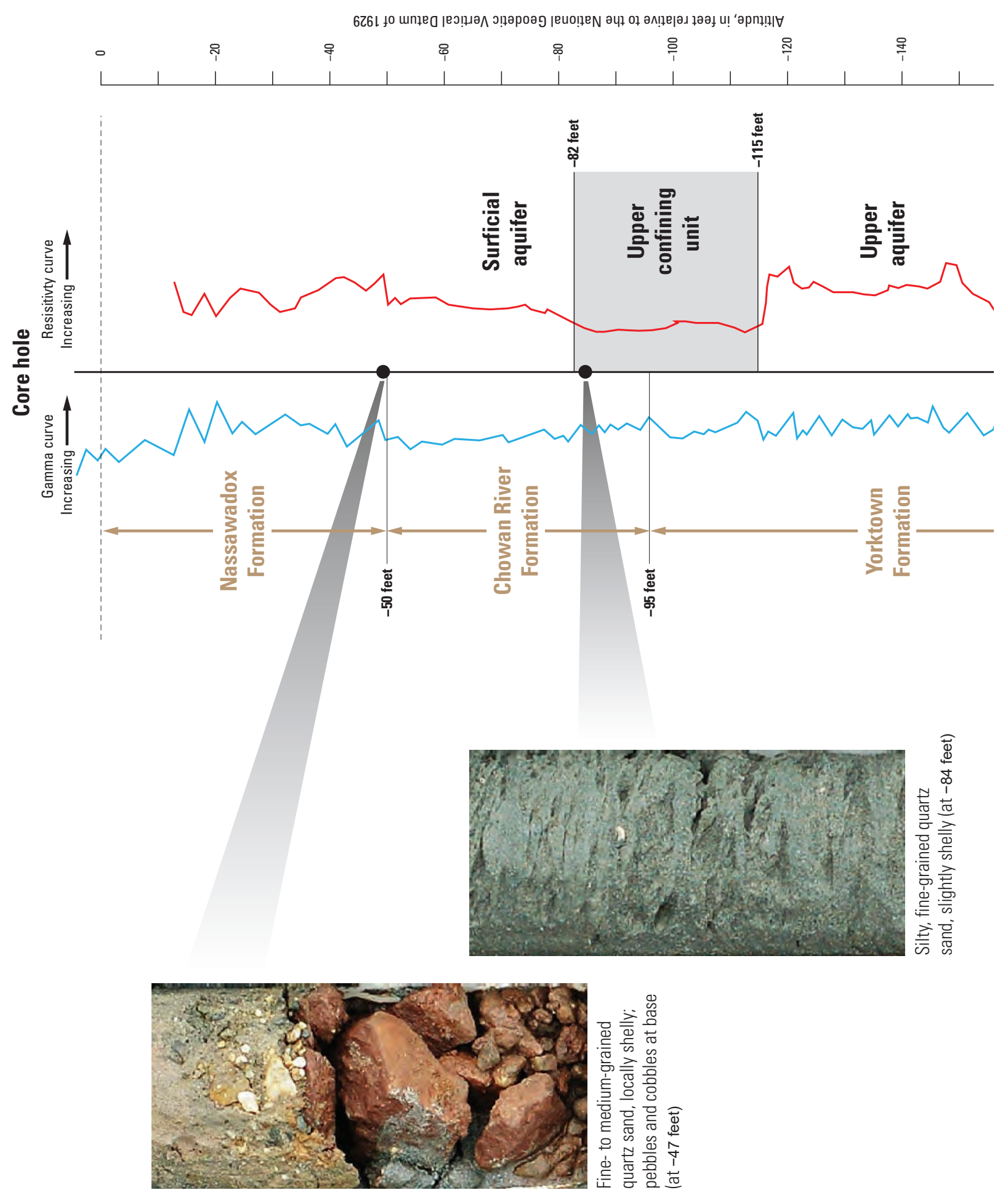



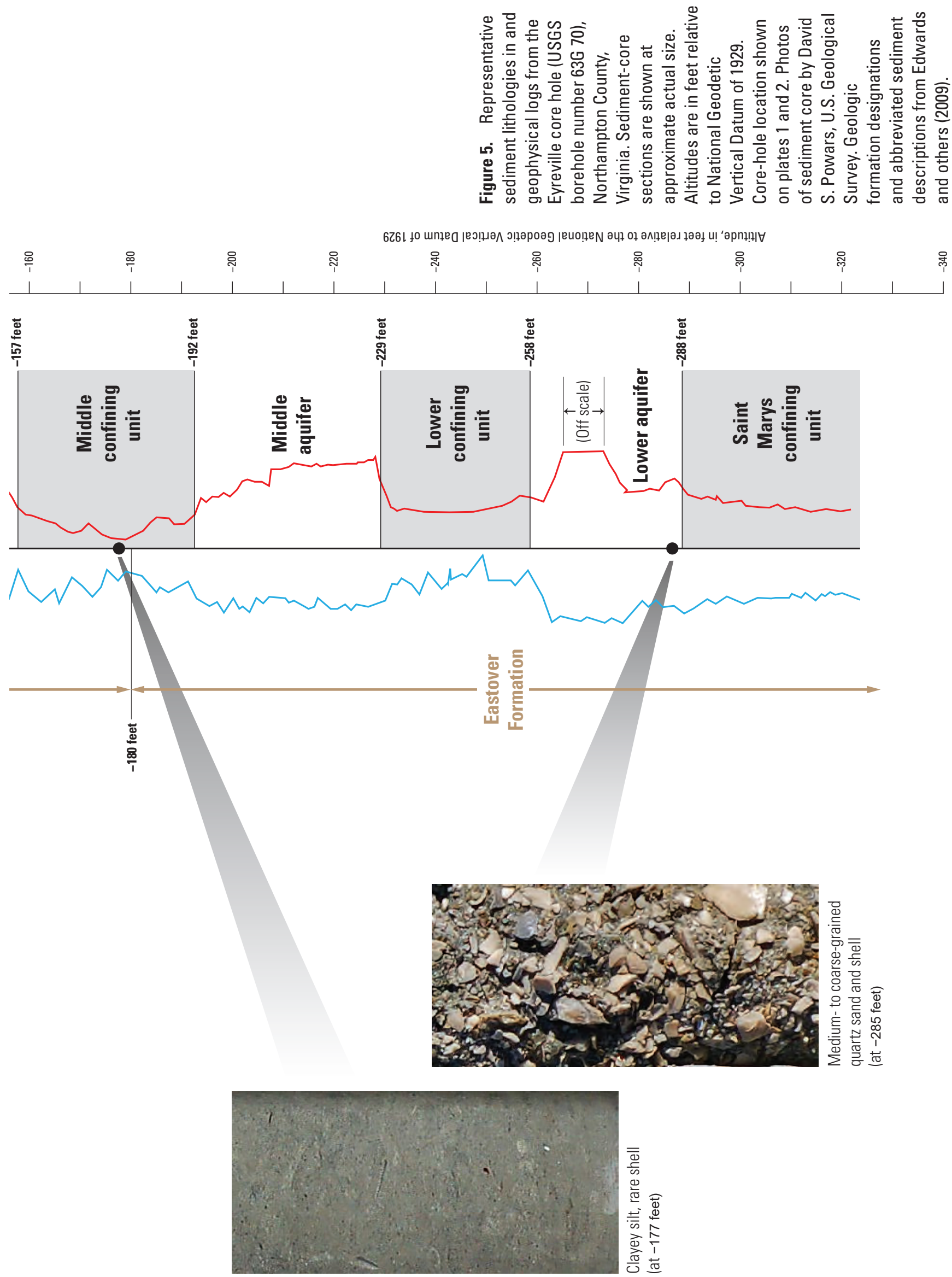
and backfilled as estuaries. The mixture of sediments from divergent sources complicates recognition of the hydrogeologic units within paleochannels. Determining the presence of paleochannels therefore relies on identification of characteristically fluvial and estuarine sediment components, such as gravel and organic material. In addition, altitudes and thicknesses of the hydrogeologic units within paleochannels in many places contrast markedly with those of nearby parts of the Yorktown-Eastover aquifer system.

\section{Configuration}

Geophysical logs and other information from a network of 205 boreholes (fig. 1, pl. 1) were analyzed to determine altitudes of the top surfaces of the layered hydrogeologic units (app. 1; McFarland, 2019). All the boreholes are located on the Virginia Eastern Shore except four that are within approximately $5 \mathrm{mi}$ to the north in Maryland. Hydrogeologic-unit top-surface altitudes were used to construct a hydrogeologic section (pl. 2) and a series of structural contour maps representing the top surfaces (pls. 3-12). Configurations of the hydrogeologic units were determined by stratigraphically correlating them across the section. Altitudes and alignments of map structural contours were interpolated between topsurface altitudes in boreholes. Because of local variability and log-scale accuracy, top-surface altitudes differ by several feet among some closely spaced boreholes.

Hydrogeologic-unit top-surface altitudes and thicknesses in the boreholes are summarized in table 1. The base of the Yorktown-Eastover aquifer system is bounded by the
Saint Marys confining unit (fig. 4). Fine-grained marine-shelf sediments of the Saint Marys confining unit extend beneath the entire Virginia Eastern Shore and beyond, into Maryland to the north and beneath Chesapeake Bay to the west and the Atlantic Ocean to the east. The top surface of the Saint Marys confining unit dips eastward beneath the Virginia Eastern Shore (pl. 3) from an altitude of approximately $-220 \mathrm{ft}$ along the shore of Chesapeake Bay to deeper than $-360 \mathrm{ft}$ along the Atlantic Coast.

The altitude of the base of the Saint Marys confining unit was not determined for this study but is below $-500 \mathrm{ft}$ and has been regionally estimated beneath the Virginia Eastern Shore at $-600 \mathrm{ft}$ (fig. 2; McFarland and Bruce, 2006). Thickness of the Saint Marys confining unit is on the order of $300 \mathrm{ft}$. An interval of relatively coarse-grained marine-shelf sediments is recognized in Maryland as the Manokin aquifer (Andreasen and others, 2013). The Manokin aquifer does not extend southward beneath the Virginia Eastern Shore more than approximately $8 \mathrm{mi}$ (pl. 2). In addition, because the Manokin aquifer in and near the Virginia Eastern Shore contains saltwater, it is not considered further here.

\section{Yorktown-Eastover Aquifer System}

Like the Saint Marys confining unit, mostly marine-shelf sediments of the Yorktown-Eastover aquifer system extend beneath the entire Virginia Eastern Shore, into Maryland, and beneath Chesapeake Bay and the Atlantic Ocean. Also like the Saint Marys confining unit, the upper, middle, and lower confined aquifers and the middle and lower confining units dip eastward (pls. 4-8). Thicknesses of these hydrogeologic

Table 1. Summary of hydrogeologic-unit top-surface altitudes and thicknesses in 205 boreholes on the Virginia Eastern Shore.

[NGVD 29, National Geodetic Vertical Datum of 1929; nd, not determined]

\begin{tabular}{|c|c|c|c|c|c|c|}
\hline & \multirow[t]{2}{*}{ Hydrogeologic unit } & \multicolumn{2}{|c|}{$\begin{array}{c}\text { Top-surface altitude } \\
\text { (feet, relative to NGVD 29) }\end{array}$} & \multicolumn{3}{|c|}{$\begin{array}{c}\text { Thickness } \\
\text { (feet) }\end{array}$} \\
\hline & & Highest & Lowest & Minimum & Mean & Maximum \\
\hline \multirow{10}{*}{ 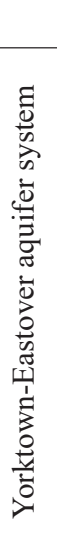 } & Surficial aquifer & 54 & 3 & 12 & 61 & 117 \\
\hline & Upper confining unit & 11 & -90 & 1 & 55 & 126 \\
\hline & Paleochannel upper aquifer & -45 & -138 & 17 & 35 & 76 \\
\hline & Paleochannel confining unit & -64 & -178 & 6 & 27 & 64 \\
\hline & Paleochannel lower aquifer & -81 & -175 & 12 & 27 & 53 \\
\hline & Upper aquifer & -48 & -166 & 15 & 47 & 96 \\
\hline & Middle confining unit & -98 & -247 & 7 & 24 & 62 \\
\hline & Middle aquifer & -108 & -275 & 8 & 36 & 74 \\
\hline & Lower confining unit & -138 & -309 & 6 & 24 & 56 \\
\hline & Lower aquifer & -161 & -320 & 24 & 43 & 68 \\
\hline & aint Marys confining unit & -218 & -370 & nd & nd & nd \\
\hline
\end{tabular}


units in boreholes collectively range from 1 to $126 \mathrm{ft}$, and their individual mean thicknesses range from 24 to $55 \mathrm{ft}$ (table 1). The altitude of the top surface of the upper aquifer is as high as approximately $-40 \mathrm{ft}$ along the shore of Chesapeake Bay (pl. 8), and the top surface of the lower aquifer is as low as approximately $-320 \mathrm{ft}$ along the Atlantic Coast (pl. 4).

\section{Top-Surface Undulations}

Top surfaces of the upper, middle, and lower aquifers, and of the middle and lower confining units, exhibit an undulating configuration (pls. 4-8). Similarly undulating top surfaces were determined in previous studies (Fennema and Newton, 1982; Richardson, 1994; Sanford and others, 2009). Details of these surfaces were limited, however, because the number of boreholes used to determine their configuration was small. Possible origins of the undulations were also not considered. The larger number of boreholes used here allows for a more detailed description. Specifically, top-surface undulations are broad beneath the northern half of Accomack County but are more closely spaced beneath the rest of the peninsula.

The top-surface undulations probably resulted partly from variations in sediment deposition. Amounts and transport directions of sediment and the configuration of the receiving basin likely changed over time to produce a nonuniform sediment distribution. Subsequent erosion could have altered the top surface of each hydrogeologic unit later, following its deposition. These processes were also possibly controlled structurally by the underlying Chesapeake Bay impact crater. All of the top surfaces exhibit a high point in far southwestern Northampton County (pls. 2-8) that coincides with the center of the inner impact crater and overlies its buried central peak. From there, top-surface undulations extend northward across the outer impact crater and are particularly pronounced for approximately an additional $15 \mathrm{mi}$.

The latter area is theorized here to constitute a disruption zone beneath southern Accomack County that is associated with the impact crater. Ongoing structural adjustment of the Earth's crust is postulated to have occurred both within and beyond the impact crater since its formation 35 million years ago (Powars and Bruce, 1999). Combinations of uplift, subsidence, and (or) faulting beneath the present-day Virginia Eastern Shore likely coincided with and controlled deposition of sediments that compose the hydrogeologic units. In contrast, parts of the hydrogeologic units farther north beneath northern Accomack County exhibit less pronounced top-surface undulations, so these areas probably were beyond the disruption zone and were less affected.

\section{Paleochannel Incision}

Hydrogeologic units of the Yorktown-Eastover aquifer system are variably incised by three paleochannels. These were named in previous studies from north to south as the Persimmon Point, Exmore, and Eastville paleochannels (fig. 1, pl. 1). Some studies (Oertel and Foyle, 1995; Hobbs, 2004;
Krantz and others, 2016) have interpolated alignments of as many as four paleochannels across the peninsula, largely on the basis of offshore marine geophysical surveys in Chesapeake Bay and the Atlantic Ocean. In this study, configurations of the paleochannels beneath the Virginia Eastern Shore were by determined by using published land-based maps of the Quaternary-age erosion surface (Mixon, 1985; Powars, 2011), which were extensively modified on the basis of analysis of geophysical logs and other information obtained from the borehole network (fig. 1, pl. 1). Each paleochannel features a southeastward-sloping mainstem and, in some cases, branching tributaries.

Depth of incision into the hydrogeologic units varies among the paleochannels. Consequently, effects of incision on the hydrogeologic units also vary. The Exmore paleochannel is the deepest and therefore affects the largest number of hydrogeologic units. The deepest part of the Exmore paleochannel is partly incised into the top of the lower aquifer across a small area near the shore of Chesapeake Bay (pl. 4, shaded area). The altitude and configuration of the top surface of the lower aquifer are altered across the incised area, which forms the bottom of the paleochannel.

The lower confining unit is positioned above the lower aquifer. Consequently, the Exmore paleochannel is incised through the entire thickness of the lower confining unit to create a structural "window" (pl. 5). Narrow margins of the window form the sidewalls of the paleochannel, along which partial incision has altered the altitude and configuration of the top surface of the lower confining unit. The bottom of the paleochannel also extends east across the partially incised area, because the slope of the paleochannel is less steep than the dip of the hydrogeologic units.

Continuing upward, the Exmore paleochannel is incised along a widening and eastward-lengthening series of windows through the middle aquifer, middle confining unit, and upper aquifer (pls. 6-8, respectively). Windows extend offshore through the middle confining unit and upper aquifer, which are thereby entirely breached by the paleochannel beneath the peninsula. Also, top surfaces are altered by incision along narrow margins of each window, which form the upwardwidening sidewalls of the paleochannel.

The configuration of the Exmore paleochannel is similar to those of the Persimmon Point paleochannel to the north and the Eastville paleochannel to the south. The Persimmon Point paleochannel is incised only as deeply as the middle aquifer (pl. 6). Two incised areas result because of variations in paleochannel slope and top-surface dip (shaded areas). Corresponding widening and lengthening windows and incised margins are in the overlying middle confining unit and upper aquifer (pls. 7 and 8, respectively). The Eastville paleochannel is the shallowest and is incised only to the middle confining unit (pl. 7). A corresponding window and incised margin are in the overlying upper aquifer (pl. 8). The mainstem of the Eastville paleochannel is wider than that of the other paleochannels, but it lacks any branching tributaries. 


\section{Upper Confining Unit}

The upper confining unit is the uppermost part of the Yorktown-Eastover aquifer system (fig. 4) and extends beneath the entire Virginia Eastern Shore, into Maryland, and beneath Chesapeake Bay and the Atlantic Ocean. It generally corresponds to the previously designated Yorktown-Eastover confining zone (figs. 2, and 4) that was regionally delineated throughout the Virginia Coastal Plain (McFarland and Bruce, 2006). The upper confining unit is composed partly of finegrained marine-shelf sediments and partly of fine-grained and organic-rich back-barrier and estuarine sediments. Thickness of the upper confining unit in boreholes ranges from 1 to $126 \mathrm{ft}$, and its mean thickness is $55 \mathrm{ft}$ (table 1). Beneath much of the Virginia Eastern Shore, the upper confining unit directly overlies the upper aquifer (pl. 2). Where paleochannels are present, however, the upper confining unit overlies the hydrogeologic units within the paleochannels.

The altitude of the top surface of the upper confining unit varies irregularly from slightly above sea level to as deep as $-90 \mathrm{ft}$ (pl. 12). Moreover, the top surface does not dip to the east as the rest of the Yorktown-Eastover aquifer system does. Instead, parts of the top surface that overlie the Persimmon Point and Exmore paleochannels broadly reflect the configurations of the paleochannels, although at an altitude several tens of feet higher. Adjacent areas generally slope toward the paleochannels. On the basis of that alignment, these parts of the top surface possibly represent a rejuvenated land-surface drainage pattern that existed prior to being buried by sediments of the surficial aquifer. To the south, the upper confining unit is deepest beneath most of Northampton County. Part of the upper confining unit that overlies the Eastville paleochannel, however, includes fine-grained sediments that fill the top of the paleochannel (pl. 2). Consequently, the top surface of the upper confining unit overlying the paleochannel is higher than the top surface in adjacent areas.

\section{Surficial Aquifer}

The surficial aquifer is regarded as separate from the Yorktown-Eastover aquifer system (fig. 4) and generally consists of medium- to coarse-grained nearshore sediments between the land surface and the top of the upper confining unit (pl. 2). The surficial aquifer underlies the entire Virginia Eastern Shore and extends into Maryland. The same sediments extend for an unknown distance offshore across the floors of the Chesapeake Bay and the Atlantic Ocean. Land-surface altitude at boreholes ranges from 3 to $54 \mathrm{ft}$, and the thickness of the surficial aquifer ranges from 12 to $117 \mathrm{ft}$ with a mean of $61 \mathrm{ft}$ (table 1).

The water table is within the surficial aquifer, above which the sediments are unsaturated. The configuration of the water table has been estimated to generally parallel that of the land surface, at altitudes close to $0 \mathrm{ft}$ near the coastline and as high as $40 \mathrm{ft}$ beneath the central spine of the peninsula (Sanford and others, 2009). Most of the surficial aquifer is probably unconfined, although sediment heterogeneity may cause locally confined conditions. In addition, the altitude of the water table typically fluctuates seasonally by several feet in response to changes in evapotranspiration and groundwater withdrawals.

\section{Hydrogeologic Units Within Paleochannels}

Three buried paleochannels contain a lower aquifer, upper aquifer, and intervening confining unit that are regarded as separate from the Yorktown-Eastover aquifer system (fig. 4). The paleochannel lower aquifer and paleochannel upper aquifer generally consist of fluvial medium- to coarse-grained sand and gravel, whereas the paleochannel confining unit consists of estuarine fine-grained sediments and organic material. All three hydrogeologic units also include reworked marineshelf sediments. They are restricted to mainstems and branching tributaries of the paleochannels (pls. 9-11) but likely extend westward beneath the Chesapeake Bay and eastward beneath the Atlantic Ocean.

Paleochannel hydrogeologic units dip generally southeastward and parallel to the slopes of the paleochannels (pls. 9-11). The altitude of the top surface of the paleochannel upper aquifer is as high as approximately $-40 \mathrm{ft}$ at the northwestern end of the Exmore paleochannel, and that of the paleochannel lower aquifer is as low as approximately $-180 \mathrm{ft}$ at the southeastern end of the Eastville paleochannel. Thicknesses in boreholes collectively range from 6 to $76 \mathrm{ft}$, and individual mean thicknesses range from 27 to $35 \mathrm{ft}$ (table 1).

Number and relative thickness of paleochannel hydrogeologic units vary among the paleochannels (pl. 2). The Exmore and Eastville paleochannels contain all three hydrogeologic units, whereas in the Persimmon Point paleochannel only the paleochannel confining unit and paleochannel upper aquifer are present. In addition, paleochannel aquifers are thicker than the paleochannel confining unit in the Persimmon Point and Exmore paleochannels, whereas the opposite is true of the Eastville paleochannel.

Paleochannel hydrogeologic units are entirely overlain by the upper confining unit of the Yorktown-Eastover aquifer system (pl. 2). They are underlain by and variably incised into deeper hydrogeologic units along an upward-widening and eastward-lengthening series of structural windows. Paleochannel hydrogeologic units thereby laterally abut those of the Yorktown-Eastover aquifer system along the sidewalls of the paleochannels. At some locations, hydrogeologic-unit altitudes and thicknesses within paleochannels contrast markedly with those in nearby parts of the Yorktown-Eastover aquifer system.

Paleochannels create the potential to hydraulically breach the Yorktown-Eastover aquifer system. Multiple aquifers and confining units within the Yorktown-Eastover system are sequentially incised along the lengths of the paleochannels (pls. 4-8). As a result, hydraulic connectivity between paleochannel aquifers and Yorktown-Eastover aquifers is complex and varies with location. Aquifer-on-aquifer contacts span parts of the paleochannels, but the extent of contact varies lengthwise. Along other parts of the paleochannels, 
the paleochannel aquifers come into contact with YorktownEastover confining units. Consequently, exchange of flow is relatively unrestricted along parts of some paleochannels but more restricted along other parts.

\section{Aquifer Hydraulic Properties}

Aquifer hydraulic properties were estimated at 58 wells (fig. 6). Summary statistics of hydraulic-property values at each well were calculated (app. 2; McFarland, 2019). The estimates were compiled from documents on file with the VA DEQ. Internal reports by agency staff that evaluate groundwater-withdrawal permit applications include results of aquifer tests. Multiple tests were performed on some wells, and multiple analyses were performed on some test data.

Consequently, agency reports include 133 estimates of aquifer transmissivity, 85 estimates of storativity, and 18 estimates of specific yield.

For this study, information on test-well locations, landsurface altitudes, screened-interval depths, and other aquifertest documentation was used in conjunction with aquifer and confining-unit top-surface altitudes to determine the aquifers in which the test wells are open. In addition, transmissivity values were divided by well-screen lengths to calculate estimates of sediment hydraulic conductivity. Incorporated in these estimates is the assumption that all flow to the test well is horizontal, and therefore that the transmissivity value represents only the sediment interval spanned by the screen. Because in many cases flow to the tested well is probably through a larger sediment interval that extends above and below the screen, the hydraulic-conductivity estimates are likely to have a high bias.

To evaluate aquifer productivity, transmissivity values are generally of greatest utility among the aquifer hydraulic properties. Accordingly, estimates of transmissivity were summarized to compare among the aquifers (table 2). Fifty-six wells that are open to a single aquifer were included in the summary; from these wells, 129 estimates of transmissivity were produced. Two additional wells that produced four estimates are open to more than one aquifer and were not included. Also, within the paleochannels, tested wells are open only to the paleochannel lower aquifer. No tested wells are open to the paleochannel upper aquifer.

On the basis of estimated values, transmissivity generally decreases with depth among the aquifers (table 2). Estimated transmissivity values were highest for the surficial aquifer and the paleochannel lower aquifer. Nearshore and fluvial sediments that compose these aquifers are among the youngest, shallowest, and most coarse grained on the Virginia Eastern Shore and are thereby likely to be the most productive. Transmissivity estimates for the surficial aquifer span a broader range and include lower values than that estimated for the paleochannel lower aquifer. The number of wells (and the number of transmissivity estimates) was greater for the surficial aquifer than for the paleochannel lower aquifer; therefore, the variability of transmissivity for the surficial aquifer may be better characterized because more data are available. Alternatively, the surficial aquifer may contain some sediments that are finer grained and have lower transmissivities than those of the paleochannel lower aquifer.

Estimates of transmissivity for the upper, middle, and lower aquifers of the Yorktown-Eastover aquifer system are generally lower than those for the surficial aquifer and paleochannel lower aquifer (table 2). Likewise, marine-shelf sediments that compose the Yorktown-Eastover aquifer system are generally finer grained than those of the surficial aquifer and paleochannel lower aquifer. Most of the sediments are also mixtures of different grain sizes, which span a continuum from the coarser grained sediments designated as aquifers to the finer grained sediments designated as confining units.

Sediments that compose the Yorktown-Eastover aquifer system are also older and deeper than those that compose the surficial aquifer and paleochannel lower aquifer. Moreover, transmissivity estimates generally decrease downward from the upper aquifer to the middle aquifer to the lower aquifer (table 2). Although sediment composition is similar among the three aquifers, their ages and depths differ considerably. Older, deeper sediments have undergone greater compaction resulting from greater overburden pressure over longer periods of time than younger shallower sediments, resulting in lower transmissivity.

Table 2. Summary of estimates of aquifer transmissivity based on results of aquifer tests on 58 wells on the Virginia Eastern Shore.

\begin{tabular}{|c|c|c|c|c|c|c|c|}
\hline \multirow{2}{*}{\multicolumn{2}{|c|}{ Hydrogeologic unit }} & \multirow{2}{*}{$\begin{array}{l}\text { Number of } \\
\text { wells }\end{array}$} & \multirow{2}{*}{$\begin{array}{l}\text { Number of } \\
\text { estimates }\end{array}$} & \multicolumn{4}{|c|}{$\begin{array}{c}\text { Transmissivity } \\
\text { (feet squared per day) }\end{array}$} \\
\hline & & & & Minimum & Mean & Median & Maximum \\
\hline \multicolumn{2}{|c|}{ Surficial aquifer } & 13 & 33 & 214 & 3,990 & 1,720 & 20,300 \\
\hline \multicolumn{2}{|c|}{ Paleochannel lower aquifer } & 6 & 23 & 1,820 & 8,060 & 5,220 & 20,300 \\
\hline \multirow{3}{*}{ 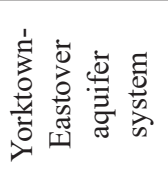 } & Upper aquifer & 19 & 30 & 143 & 2,150 & 2,040 & 8,270 \\
\hline & Middle aquifer & 10 & 24 & 30 & 836 & 342 & 4,370 \\
\hline & Lower aquifer & 8 & 19 & 133 & 686 & 368 & 2,080 \\
\hline
\end{tabular}




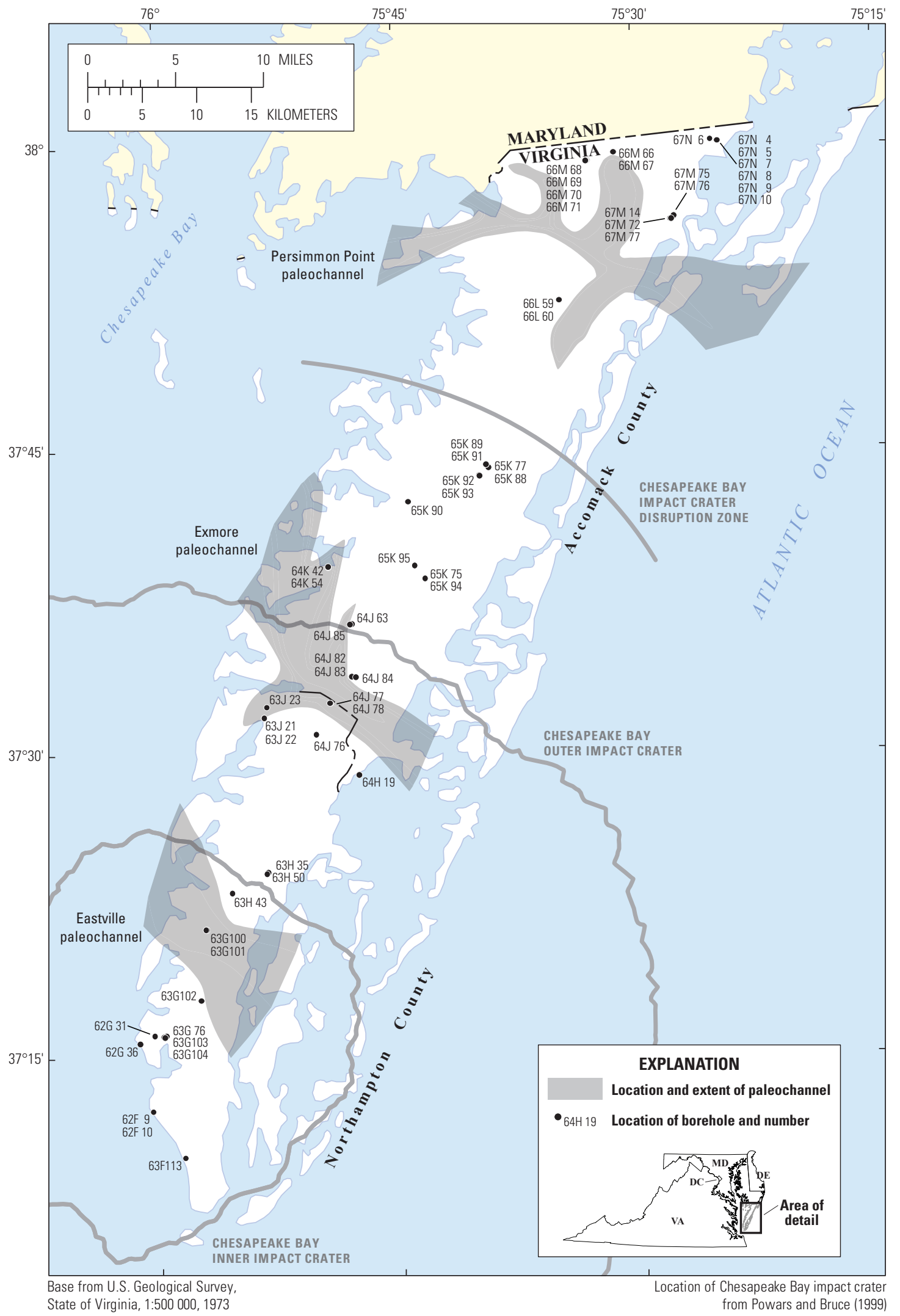

Figure 6. Locations and numbers of aquifer-test wells on the Virginia Eastern Shore. 


\section{Saltwater-Transition Zone}

The chemical composition of groundwater beneath the Virginia Eastern Shore has been characterized regionally as freshwater containing mostly calcium cations and bicarbonate anions at low concentrations, and saltwater containing mostly sodium cations and chloride anions at higher concentrations (McFarland, 2010). Fresh groundwater is present only in shallow sediments to depths generally less than $300 \mathrm{ft}$. Underlying sediments as much as several thousand feet deep contain dense, stagnant saltwater mounded over the Chesapeake Bay impact crater (fig. 2).

Geologic and hydrochemical evidence indicates that much of the saltwater beneath the Virginia Coastal Plain originated from seawater (McFarland and Bruce, 2005; McFarland, 2010). Seawater has been repeatedly emplaced within subsurface sediments during cycles of submersion by the Atlantic Ocean over the past approximately 65 million years. During emergent periods, fresh groundwater has flushed seawater from the sediments.

Precipitation on the Virginia Eastern Shore percolates to the water table and flows either through the surficial aquifer to discharge at the land surface or leaks downward into deeper aquifers. Upon encountering the underlying, denser saltwater, fresh groundwater leaks back upward to discharge along the coastline to Chesapeake Bay and the Atlantic Ocean (fig. 2). The freshwater and saltwater merge across the saltwatertransition zone, which imposes a landward-sloping boundary on the flow of fresh groundwater. Dispersive mixing between freshwater and saltwater takes place along the saltwater-transition zone across a density gradient.

As a boundary on fresh groundwater flow, the saltwatertransition zone is an integral component of the hydrogeologic framework. Moreover, from a water-quality perspective, the presence of saltwater makes chloride a chemical constituent of primary concern for resource management. A secondary maximum contaminant level (SMCL) of $250 \mathrm{mg} / \mathrm{L}$ has been established for chloride (U.S. Environmental Protection Agency, 1990). Seawater has a chloride concentration of approximately $19,000 \mathrm{mg} / \mathrm{L}$ (Hem, 1985). Thus, a proportion of seawater in drinking water as small as 1 part in 76 is enough to cause the chloride concentration to meet or exceed the chloride SMCL.

The position of the saltwater-transition zone can move in response to groundwater withdrawals. Consequently, chloride concentrations in pumped wells can increase. Where groundwater levels have declined below sea level, the resulting landward horizontal hydraulic gradient creates the potential for inland lateral intrusion of saltwater. On the basis of estimates of groundwater age and linear velocities, however, lateral intrusion beneath the Virginia Coastal Plain generally requires decades to cross distances as short as $1 \mathrm{mi}$ (McFarland, 2010). Likewise, once lateral intrusion occurs, similar timeframes would likely be required to mitigate the resulting elevated chloride concentrations.

Alternatively, the saltwater-transition zone can move upward directly beneath pumped wells by a process known as upconing. Because of a density equilibrium maintained between freshwater and underlying saltwater, any decline in groundwater levels (even if remaining above sea level) results in a corresponding rise in the saltwater-transition zone (McFarland, 2015). In addition, vertical distances between the open intervals of pumped wells and the underlying saltwatertransition zone can be as small as a few tens of feet. Consequently, most increases in chloride concentration in pumped wells in the Virginia Coastal Plain likely result from upconing rather than lateral intrusion (McFarland, 2010), and in some cases occur over periods as short as several weeks. Likewise, cessation or reduction of pumping for groundwater levels to recover can allow the altitude of the saltwater-transition zone to decline within similar timeframes.

\section{Groundwater Chloride Concentrations}

Chloride concentrations in groundwater samples collected from 330 wells on the Virginia Eastern Shore (pl. 13) were compiled from the USGS National Water Information System database (U.S. Geological Survey, 2017), the VA Hydro databases of the VA DEQ, and published sources (McFarland, 2010; Fennema and Newton, 1982). Chloride concentrations as well as data sources, well locations, and collection dates are tabulated for 2,440 samples collected during 1906-2016 (app. 3A; McFarland, 2019). For this study, sample altitudes were calculated as the midpoint of the open interval of each well. Multiple wells are vertically nested at some locations. In addition, well identifiers 63G 69 and 63G 70 designate 12 vertically spaced samples of pore water that were extracted from sediment cores.

Sample ion-charge balance values were calculated as a data quality-assurance measure. For samples that were analyzed for all major ions, chloride concentrations were retained only for samples having charge-balance values within plus or minus 5 percent. Chloride concentrations also were retained, but charge balance was not calculated for samples that were not analyzed for all major ions.

Other than charge-balance screening, the chloride concentrations are presented essentially as obtained from the original data sources except that concentration values are rounded to no more than three significant figures. The samples were collected and analyzed by many individuals and diverse organizations spanning a century-long period. Limits of analytical precision are not uniformly documented but likely vary widely among the different data sources and through time. Hence, concentration values should not be assumed to represent data that conform to analytical precision limits or other measures of accuracy.

Summary statistics of groundwater chloride concentration at each well were calculated (app. 3B; McFarland, 2019). Most wells having large ranges in concentration include one or two samples with anomalously small or large values that contrast markedly with values for other samples from the same well. Supportive information is not adequate to evaluate whether these concentrations represent sample blanks or 
spikes, or alternatively are the result of errors in sample collection, analysis, or data management. Data users are advised to view anomalous values with caution.

Most of the wells were not sampled frequently. During 1906-2016, nearly half of the wells were sampled only once, and 83 percent were sampled fewer than 10 times. Consequently, changes in chloride concentration over time can be indicated at only relatively few wells. Among wells that were sampled more than once, periods of collection range roughly equally between those with less than 5 years, 5 to 20 years, and longer than 20 years. On the basis of visual examination of the compiled data, wells having appreciable collection periods and numbers of samples showed fluctuating concentrations that both increased and decreased over time. These fluctuations probably reflect localized saltwater upconing and downconing caused by variations in nearby pumping. None of the wells showed consistently increasing concentrations that would indicate long-term lateral intrusion of saltwater.

\section{Configuration}

The chloride concentrations were used to delineate the configuration of the saltwater-transition zone. Mean sample chloride concentrations from selected wells located at and near the hydrogeologic section are plotted on the section in plate 2 . Chloride concentrations generally increase with depth. Most of the samples were collected at altitudes above $-300 \mathrm{ft}$ and contained chloride at concentrations that were less than the 250-mg/L SMCL. Samples having larger concentrations were collected at relatively low altitudes. In addition, vertically spaced samples of pore water that were extracted from sediment cores in and near borehole 63G 70 increased with depth to as much as $10,500 \mathrm{mg} / \mathrm{L}$ at an altitude near $-500 \mathrm{ft}$ (pl. 2).

Chloride concentrations shown on the hydrogeologic section are vertically bracketed by a $250-\mathrm{mg} / \mathrm{L}$ concentration contour and a $1,000-\mathrm{mg} / \mathrm{L}$ concentration contour that together depict the configuration of the saltwater-transition zone (pl. 2). Toward the southern end of the hydrogeologic section near the shore of Chesapeake Bay, the saltwater-transition zone is abruptly elevated by approximately $150 \mathrm{ft}$ and samples containing chloride at large concentrations are found at relatively high altitudes. Likewise, the saltwater-transition zone is elevated toward the northern end of the section near the Atlantic Ocean.

The 250-mg/L chloride-concentration contour on the hydrogeologic section (pl. 2) represents a three-dimensional trace of a surface of equal concentration that projects through the vertical plane of the hydrogeologic section. Accordingly, all sample concentrations were used to areally delineate the 250-mg/L chloride-concentration surface beneath the Virginia Eastern Shore (pl. 13). The position of the chlorideconcentration surface was interpolated among altitudes of samples having different chloride concentrations. The chloride surface on the Virginia Eastern Shore was delineated previously but was based on concentrations in samples from only
15 wells (Fennema and Newton, 1982). Additional detail is provided here by including samples from 330 wells. A series of similar surfaces of various groundwater chloride concentrations beneath the entire Virginia Coastal Plain, delineated by McFarland (2010), can be used for comparison. Traces of these surfaces appear as chloride-concentration contours on the hydrogeologic section of the Virginia Coastal Plain in figure 2.

The 250-mg/L groundwater chloride-concentration surface reflects the configuration of the saltwater-transition zone. The chloride surface is represented by contour lines that indicate the altitude of groundwater having a concentration of $250 \mathrm{mg} / \mathrm{L}$ at various locations (pl. 13). Both the chlorideconcentration surface altitude contours and the $250-\mathrm{mg} / \mathrm{L}$ concentration contour on the hydrogeologic section indicate the saltwater-transition zone to have a broad, trough-like shape aligned with the peninsula. The saltwater-transition zone is relatively shallow along the coastline and generally deeper near the central spine of the peninsula. Deepest parts of the chloride surface approximately coincide with the base of the lower aquifer at the top of the Saint Marys confining unit.

The configuration of the saltwater-transition zone largely reflects groundwater flow prior to widespread groundwater withdrawals. The age of groundwater in the YorktownEastover aquifer system is estimated to be thousands to tens of thousands of years (Sanford and others, 2009). Although water levels currently (2019) are below sea level at some locations and create the potential for lateral saltwater intrusion, groundwater movement is too slow to have traversed appreciable distances. Instead, deep parts of the saltwater-transition zone reflect downward leakage of fresh groundwater into the Yorktown-Eastover aquifer system. Likewise, shallower parts of the saltwater-transition zone along the coastline reflect upward leakage and discharge to Chesapeake Bay and the Atlantic Ocean.

\section{Saltwater Ridge}

The saltwater-transition zone is generally deep near the central spine of the peninsula and shallow along the coastline. Chloride concentrations in some samples from wells located across the center of the peninsula, however, are high at relatively high altitudes (pl. 2). This part of the $250-\mathrm{mg} / \mathrm{L}$ groundwater chloride-concentration surface exhibits a ridgelike feature that spans the center of the peninsula (pl. 13). The anomalous ridge in the chloride surface was first delineated 37 years ago (Fennema and Newton, 1982), but no explanation for its presence was offered. Estimates of groundwater levels prior to widespread groundwater withdrawals are as much as $25 \mathrm{ft}$ lower in this area than along parts of the central spine to the north and south (fig. $3 A$ ).

Although groundwater withdrawals can elevate the altitude of the saltwater-transition zone by upconing, the saltwater ridge probably did not result solely from withdrawals. Low groundwater levels that align with the saltwater ridge 
are estimated to predate widespread groundwater withdrawals (fig. $3 A$ ) and to have remained relatively stable (figs. $3 B$ and $3 C$ ). In contrast, withdrawals have resulted in large waterlevel declines at other locations to the north, but they have not elevated the altitude of the saltwater-transition zone.

Alternatively, the Exmore paleochannel is also aligned with the saltwater ridge and possibly contributed to its formation. The Exmore is the deepest of the paleochannels and is the only paleochannel that is incised into all the aquifers of the Yorktown-Eastover aquifer system (pls. 4-8). Within the Exmore paleochannel, the paleochannel lower aquifer has among the highest estimated transmissivity values (table 2). Along the sidewalls of the paleochannel, permeable sediments that fill the paleochannel hydraulically breach confining units and laterally abut the upper, middle, and lower aquifers to create a substantial flow conduit.

Considering the above, one possible explanation for the saltwater ridge is that the Exmore paleochannel has acted as a large lateral collector drain (fig. 7). Prior to widespread withdrawals, groundwater that would otherwise flow directly toward and discharge along the coastline could have been intercepted from areas north and south of the paleochannel.
Hydraulic effects of the Exmore paleochannel would be similar to those of a pumped well that induces upconing. Groundwater levels were lowered and, in response, the saltwatertransition zone below the paleochannel was elevated to create the saltwater ridge. Groundwater that entered paleochannel sediments from adjacent aquifers would have continued to flow along the paleochannel to discharge to the Chesapeake Bay and (or) the Atlantic Ocean.

Hydrologic effects associated with the Exmore paleochannel are not apparent with the Persimmon Point and Eastville paleochannels. The available data may not be adequate to fully characterize conditions associated with these paleochannels or, alternatively, the Persimmon Point and Eastville paleochannels may not cause substantial hydrologic effects. Neither of these paleochannels is incised as deeply into the Yorktown-Eastover aquifer system as the Exmore paleochannel. The Persimmon Point paleochannel is incised as deeply as the middle aquifer, but the middle aquifer is primarily in contact with the paleochannel confining unit (pl. 2). The overlying paleochannel upper aquifer is in contact only with the Yorktown-Eastover upper aquifer and therefore may not create a substantial flow conduit. In the Eastville paleochannel,

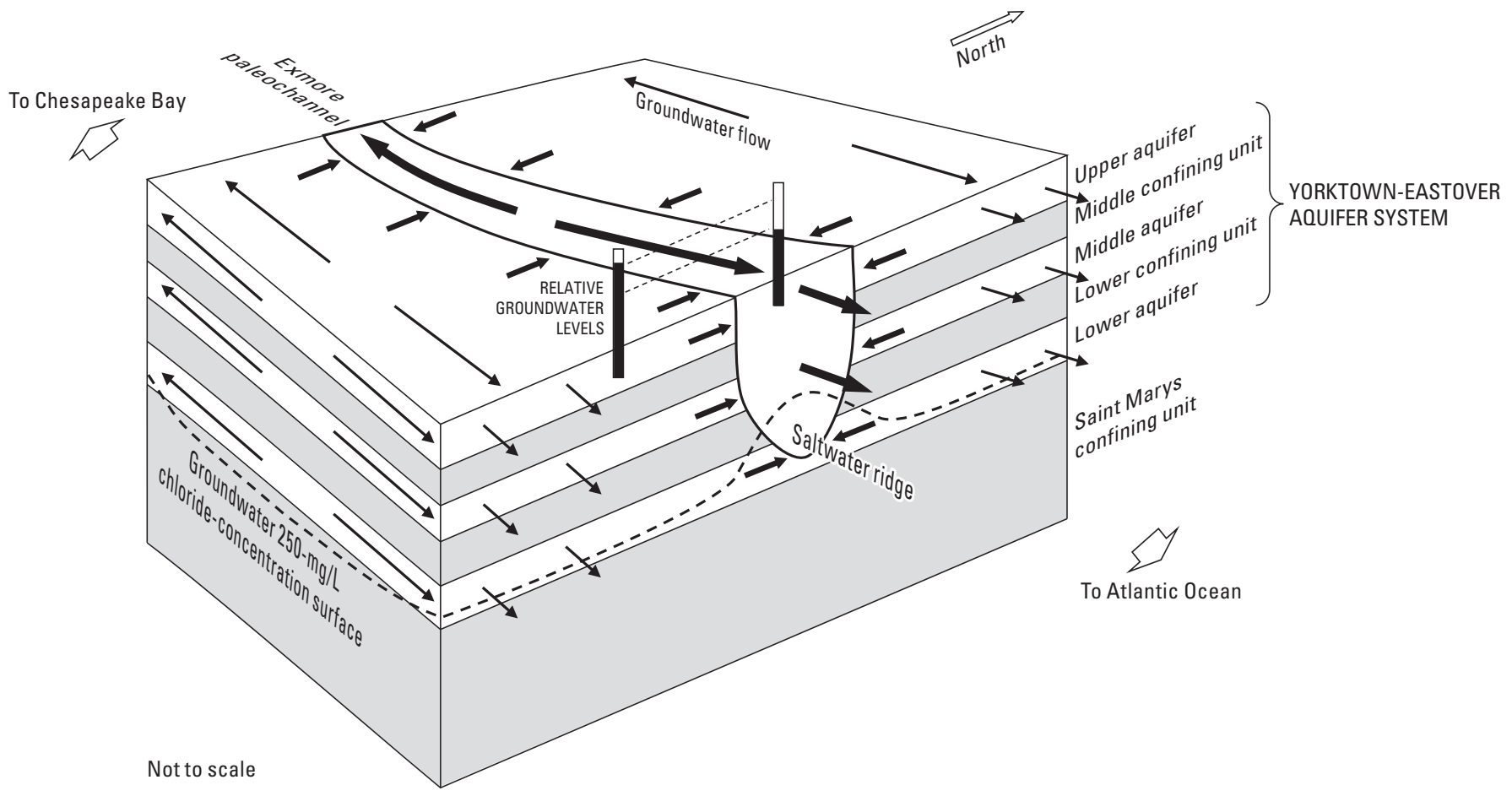

Figure 7. Generalized hydrologic relations among aquifers and the Exmore paleochannel on the Virginia Eastern Shore. The surficial aquifer and upper confining unit are omitted for clarity. Hydrogeologic units within the Exmore paleochannel are not distinguished. Weight of arrow denotes relative flow rate. $\mathrm{mg} / \mathrm{L}$, milligrams per liter. 
thick, fine-grained sediments of the paleochannel confining unit may create a north-south barrier to flow across the upper aquifer (pl. 2). This is unlikely, however, because predominant prewithdrawal directions of flow were either to the west toward Chesapeake Bay or to the east toward the Atlantic Ocean, and were unaffected.

\section{Information Uses and Limitations}

The hydrogeologic framework of the Virginia Eastern Shore can potentially be used to aid in water-supply planning and development by reducing uncertainty associated with the design and siting of production wells. Construction of highyielding wells can be facilitated by site-specific estimation of aquifer depths, thicknesses, and hydraulic properties. More widely, the potential for proposed groundwater development among planning areas can be assessed on the basis of broad comparisons of aquifer configurations and productivity.

For both site-specific estimates and area-wide planning, proximity to saltwater can be considered to avoid chloride contamination of water-supply wells. The most problematic areas for chloride contamination are the shallowest parts of the saltwater-transition zone along the coastline and across the central saltwater ridge. Likewise, the saltwater-transition zone is generally deepest near the central spine of the peninsula, where wells can be positioned farthest from saltwater.

\section{Digital Model Improvement}

Previously constructed digital models (Richardson, 1994; Sanford and others, 2009) have been used by the VA DEQ to evaluate both site-specific and area-wide effects of groundwater withdrawals on the Virginia Eastern Shore. The hydrogeologic framework presented here can be incorporated into a revised model having improved capabilities. Expanded data from boreholes, aquifer tests, and groundwater samples generally provide greater accuracy on aquifer configurations, hydraulic properties, and proximity to saltwater than was available when the earlier models were constructed.

Of particular importance to model improvement are the aquifers that are newly delineated here within buried paleochannels that hydraulically breach the Yorktown-Eastover aquifer system. Earlier models do not represent buried paleochannels distinctly as delineated aquifers, but rather only indirectly approximate their possible hydraulic effects by varying assumed sediment hydraulic-property values assigned to parts of some confined-aquifer model layers. A revised model could include a more detailed and realistic representation of hydraulic connections between the paleochannel aquifers and nearby parts of the Yorktown-Eastover aquifer system. Estimates of paleochannel-aquifer hydraulic properties can provide a basis with which to constrain assigned values during model calibration. Whether the paleochannels create flow barriers or conduits could thereby be determined.
Possible withdrawal-induced preferential flow paths through the paleochannels, and their role in lateral saltwater intrusion, could then be evaluated.

The capability of earlier models to simulate movement of saltwater is also limited by representation of the lower aquifer that includes an underlying no-flow boundary. As a result, vertical movement of saltwater from beneath the lower aquifer cannot be simulated. Increased chloride concentrations in pumped wells, however, probably result most commonly from upconing directly beneath the wells. The $250-\mathrm{mg} / \mathrm{L}$ groundwater chloride-concentration surface delineated here is near the base of the lower aquifer at the top of the Saint Marys confining unit. Accordingly, instead of a no-flow boundary beneath the lower aquifer, a revised model that includes leakage from the Saint Marys confining unit could potentially be used to simulate upward movement of the saltwater-transition zone.

\section{Limitations}

Use of the hydrogeologic framework has limitations. Direct observation of sediment composition was limited in this study to information from boreholes. Configurations of the aquifers and confining units are interpolated between - and in some places extrapolated beyond - the borehole locations. Locations of the boreholes are also not uniformly distributed, and top-surface altitudes among closely spaced boreholes can differ by several feet because of local variability and log-scale accuracy. As a result, subjectivity was required in delineating the aquifers and confining units across many areas. Maps of top-surface structural contours (pls. 3-12) provide a general indication of surface altitudes at various locations but are limited to broad trends. Confidence in altitudes estimated at locations near boreholes is relatively strong, but confidence in areas that lack nearby data control is more limited.

Limitations of particular importance concern the sediment composition and configuration of buried paleochannels. This study relied on published land-based maps of the Quaternary-age erosion surface (Mixon, 1985; Powars, 2011) that were extensively modified on the basis of geophysical logs and other borehole information. Recognition of paleochannel sediments in boreholes, however, is complicated by mixtures of sediment from divergent sources. In addition, the multiple hydrogeologic units within each paleochannel indicate that the sediments likely had a complex depositional history involving repeated episodes of incision and backfilling, but paleochannel-sediment deposition is not yet fully elucidated by active research.

On the basis of the limitations described above, this first explicit delineation of paleochannel sediments as distinct hydrogeologic units is preliminary. Alignments of paleochannel mainstems, their branching tributaries (where present), and their offshore extents remain uncertain. Improved characterization of the paleochannels is predicated on information from additional boreholes, augmentative means of spatial delineation such as surface geophysical surveys, and reconstruction of 
a more detailed and complete depositional history. Hydraulic connections between paleochannels and adjacent parts of the Yorktown-Eastover aquifer system could be evaluated by means of appropriately designed aquifer tests.

Similarly, characterization of the saltwater-transition zone is preliminary. Delineation of the $250-\mathrm{mg} / \mathrm{L}$ groundwater chloride-concentration surface on the basis of data from samples collected from 330 wells is an improvement on its first delineation 37 years ago (Fennema and Newton, 1982), which was based on analyses of samples from only 15 wells. Sample chloride concentrations were compiled from diverse sources, however, and are not fully documented with regard to accuracy or methods of sample collection, analysis, and data management. In addition, sample locations are not uniformly distributed, and chloride concentrations at some locations varied over time. As a result, subjectivity was required in interpolating the configuration of the chloride-concentration surface between sample locations. Chloride-surface contours (pl. 13) provide a general indication of $250-\mathrm{mg} / \mathrm{L}$ surface altitudes at various locations, but are limited to broad trends.

Possible movement of the saltwater-transition zone also is not characterized here. Most wells included in this study were sampled only once or a few times. Information about changes in chloride concentration over time is limited to relatively few wells showing fluctuating concentrations, which probably reflect upconing resulting from variations in nearby pumping rather than long-term lateral saltwater intrusion. Regionwide characterization of changes in chloride concentration is a critical prerequisite for effectively simulating saltwater movement.

A strategy for monitoring movement of saltwater has been developed for the mainland part of the Virginia Coastal Plain groundwater system (McFarland, 2015). Elements of that strategy include (1) prioritization for monitoring among groundwater-withdrawal locations based on their proximities to $250-\mathrm{mg} / \mathrm{L}$ and $1,000-\mathrm{mg} / \mathrm{L}$ groundwater chloride-concentration surfaces, and (2) guidelines for appropriate construction and sampling of monitoring wells for this setting and purpose. A similar approach developed and implemented on the Virginia Eastern Shore could potentially be used to detect changes in the position of the saltwater-transition zone.

In addition to conventional well sampling, electromagnetic-induction (EM) well-logging techniques could potentially augment monitoring of saltwater movement on the Virginia Eastern Shore. EM logging can indirectly detect relative changes in groundwater salinity over periods of months to decades by repeatedly measuring sediment electrical conductance across the vertical interval of the well (Prinos and Valderrama, 2016). EM logging has advantages over sampling in that it is less costly and time consuming, thereby enabling relatively frequent measurements over sufficiently long periods to reliably detect salinity changes. Conventional sampling of logged wells is still needed, however, to establish a baseline of directly observed salinity to which EM logs can be calibrated. In addition, only wells cased with nonconductive polyvinyl chloride (PVC) rather than conductive steel can be logged. Compared to the mainland part of the Virginia Coastal
Plain, the Virginia Eastern Shore is advantaged in already having a relatively large proportion of existing PVC-cased wells. Establishing a network of wells having an adequately uniform spatial coverage and periodically logged over a sufficiently long period could potentially detect saltwater movement.

\section{Summary and Conclusions}

The Virginia Eastern Shore forms the southernmost part of the Delmarva Peninsula within the Virginia Coastal Plain. Sound scientific understanding of the Virginia Eastern Shore is needed to support effective decision making for groundwater development and management. Nearly all freshwater is supplied by groundwater withdrawals that have lowered water levels, altered hydraulic gradients, and created the potential for saltwater intrusion. The Virginia Department of Environmental Quality (VA DEQ) and local planners have relied on previous characterizations of groundwater conditions to manage the resource, but these were limited by a lack of hydrogeologic information. In particular, improved data on buried paleochannels that could alter groundwater flow and saltwater movement are critical to safeguarding the groundwater supply.

Using recently available expanded information, the U.S. Geological Survey (USGS) undertook a study in cooperation with the VA DEQ during 2016-19 to develop an improved description of the groundwater system, or hydrogeologic framework. On the basis of geophysical logs and other information from 205 boreholes, Miocene- to Pliocene-age marineshelf sediments of the Yorktown-Eastover aquifer system are designated to include upper, middle, and lower confined aquifers overlain by correspondingly named confining units and underlain by the Saint Marys confining unit. The aquifers are composed of medium- to coarse-grained sand and shell and the confining units consist of fine-grained sand, silt, and clay. The upper confining unit also includes fine-grained and organic-rich back-barrier and estuarine sediments of Pleistocene age. An overlying surficial aquifer is composed mostly of Pleistocene-age nearshore sand and gravel with smaller amounts of cobbles and boulders.

In addition - and newly designated here-Pleistoceneage fluvial and estuarine sediments of two aquifers and one confining unit are restricted to three buried paleochannels. This characterization is the first explicit delineation of sediments that fill the paleochannels as distinct hydrogeologic units. The aquifers consist of medium- to coarse-grained sand and gravel, and the intervening confining unit consists of finegrained sand, silt, clay, and organic material. Aquifer and confining-unit sediments are also mixed with reworked marineshelf sediments eroded from the sides of the paleochannels.

Layered sediments of the Yorktown-Eastover aquifer system and underlying Saint Marys confining unit dip eastward and extend beneath the entire Virginia Eastern Shore and beyond. Aquifers and confining units range in thickness from less than 10 feet (ft) to several tens of feet, and widely exhibit 
an undulating configuration that possibly resulted structurally from the underlying Chesapeake Bay impact crater. The aquifers and confining units are also variably incised by three paleochannels along an upward-widening and eastwardlengthening series of structural "windows." The upper confining unit overlies the upper aquifer and-where present- the paleochannels. Parts of the upper confining unit top surface possibly represent a rejuvenated land-surface drainage pattern before it was buried by sediments of the surficial aquifer.

Hydrogeologic units within three buried paleochannels are limited to mainstems and branching tributaries of the paleochannels. The hydrogeologic units dip southeastward parallel to slopes of the paleochannels and likely extend beneath the Chesapeake Bay and the Atlantic Ocean. Two aquifers and one confining unit vary among the paleochannels in number and relative thickness, ranging from less than $10 \mathrm{ft}$ to several tens of feet. Paleochannel hydrogeologic units laterally abut those of the Yorktown-Eastover aquifer system along the sidewalls of the paleochannels and thereby create the potential to hydraulically breach the Yorktown-Eastover aquifer system. Localized barriers to or conduits for groundwater flow can alternately result between paleochannel hydrogeologic units and the Yorktown-Eastover aquifer system.

Estimated aquifer hydraulic properties at 58 wells on the Virginia Eastern Shore were compiled from records on file with the VA DEQ. Results of documented aquifer tests include 133 estimates of aquifer transmissivity, 85 estimates of storativity, and 18 estimates of specific yield. Estimates of transmissivity indicate differences in productivity among the aquifers. Transmissivity is generally greatest in young, shallow, and coarse-grained nearshore and fluvial sediments of the surficial aquifer and paleochannel lower aquifer. Transmissivity progressively decreases with depth in older, deeper, and finer grained marine-shelf sediments of the Yorktown-Eastover aquifer system, probably because they have undergone compaction resulting from greater overburden pressure over longer periods of time.

Chloride concentrations in 2,440 samples collected from 330 wells on the Virginia Eastern Shore during 1906-2016 were compiled from databases of the USGS and VA DEQ and from published sources. Chloride concentration generally increases downward, with most of the samples collected at altitudes above $-300 \mathrm{ft}$ and having concentrations less than the 250-milligram-per-liter (mg/L) U.S. Environmental Protection Agency secondary maximum contaminant level. Chloride concentrations plotted on a hydrogeologic section and used to delineate a $250-\mathrm{mg} / \mathrm{L}$ chloride-concentration surface indicate that the saltwater-transition zone has a broad, trough-like shape aligned with the peninsula. Saltwater is relatively shallow along the coastline and generally deeper near the central "spine" of the peninsula, approximately coinciding with the top of the Saint Marys confining unit. Because groundwater moves slowly, this configuration largely reflects groundwater flow prior to widespread groundwater withdrawals. Deep parts of the saltwater-transition zone reflect downward leakage of fresh groundwater into the Yorktown-Eastover aquifer system, whereas shallower parts result from upward leakage and discharge along the coastline.

The saltwater-transition zone is elevated across an anomalous ridge that spans the center of the peninsula and is aligned with the Exmore paleochannel. Groundwater levels indicate that the saltwater ridge probably did not result solely from withdrawals, but rather that the Exmore paleochannel has acted as a large lateral collector drain. The Exmore is the deepest of the paleochannels, has among the highest transmissivities, and is incised into and hydraulically breaches the entire Yorktown-Eastover aquifer system to create a substantial flow conduit. Prior to widespread groundwater withdrawals, groundwater that otherwise would have flowed toward and discharged along the coastline was intercepted by the Exmore paleochannel which-like a pumped well-lowered groundwater levels and elevated the saltwater-transition zone. The other two paleochannels did not produce the same effects, probably because they are shallower and do not hydraulically breach the Yorktown-Eastover aquifer system in a manner that creates flow conduits.

The hydrogeologic framework described here can be used to aid water-supply planning and development by reducing the uncertainty of production-well design and siting. Groundwater-development potential and construction of high-yielding wells can be based on broad aquifer trends, site-specific aquifer properties, and proximity to saltwater to avoid chloride contamination. The accuracy of digital models used to evaluate effects of groundwater withdrawals can also be generally improved on the basis of expanded data. Whether hydraulic connections between paleochannels and the Yorktown-Eastover aquifer system create flow barriers or conduits, and consequently preferential flow paths for saltwater intrusion, can be evaluated. In addition, including leakage from the underlying Saint Marys confining unit in a model design could potentially support simulation of upconing of the saltwater-transition zone from the base of the lower aquifer.

The hydrogeologic framework is limited by observation of sediment composition from nonuniformly distributed boreholes and the resulting subjectivity in delineating aquifers and confining units. Particularly, this first explicit delineation of sediments that fill the paleochannels as distinct hydrogeologic units is considered to be preliminary. Similarly, subjectivity was required in interpolating a $250-\mathrm{mg} / \mathrm{L}$ groundwater chloride-concentration surface from analyses of nonuniformly distributed groundwater samples. Consequently, the configuration of the saltwater-transition zone is also considered to be preliminary. In addition, movement of the saltwater-transition zone is not characterized because most wells were not sampled with adequate frequency. A monitoring strategy using conventional well sampling possibly augmented with electromagnetic-induction well logging could potentially be used to detect changes in the position of the saltwater-transition zone. 


\section{References Cited}

Andreasen, D.C., Staley, A.W., and Achmad, Grufron, 2013, Maryland Coastal Plain Aquifer Information SystemHydrogeologic framework: Maryland Geological Survey Open-File Report 12-02-20, 121 p., accessed August 19, 2019, at http://www.mgs.md.gov/publications/report_pages/ OFR_12-02-20.html.

Bal, G.P., 1977, Computer simulation model for groundwater flow in the Eastern Shore of Virginia: Virginia State Water Control Board Supplement to Planning Bulletin 309, 67 p.

Browning, J.V., Miller, K.G., McLaughlin, P.P., Edwards, L.E., Kulpecz, A.A., Powars, D.S., Wade, B.S., Feigenson, M.D., and Wright, J.D., 2009, Integrated sequence stratigraphy of the postimpact sediments from the Eyreville core holes, Chesapeake Bay impact structure inner basin, in Gohn, G.S., Koeberl, Christian, Miller, K.G., and Reimold, W.U., eds., The ICDP-USGS deep drilling project in the Chesapeake Bay impact structure-Results from the Eyreville core holes: Geological Society of America Special Paper 458, p. 775-810.

Commonwealth of Virginia, 1975, Groundwater conditions in the Eastern Shore of Virginia: Virginia State Water Control Board Planning Bulletin 45, $59 \mathrm{p}$.

Commonwealth of Virginia, 1977, Groundwater conditions in the Eastern Shore of Virginia Accomack County: Virginia State Water Control Board Planning Bulletin 45, Supplement, $14 \mathrm{p}$.

Commonwealth of Virginia, 1978, Groundwater conditions in the Eastern Shore groundwater management area, Virginia: Virginia State Water Control Board, Planning Bulletin 45, Supplement no. 2, 20 p.

Commonwealth of Virginia, 1992, Certain withdrawals; permit not required, sec. 62.1-259 of Waters of the State, Ports and Harbors: Commonwealth of Virginia Code of Virginia, title 62.1, accessed August 13, 2019, at https://law.lis. virginia.gov/vacode/title62.1/chapter25/section62.1-259/.

Cushing, E.M., Kantrowitz, I.H., and Taylor, K.R., 1973, Water resources of the Delmarva Peninsula: U.S. Geological Survey Professional Paper 822, 58 p., 12 pls.

Edwards, L.E., Powars, D.S., Browning, J.V., McLaughlin, P.P., Miller, K.G., Self-Trail, J.M., Kulpecz, A.A., and Elbra, Tiiu, 2009, Geologic columns for the ICDP-USGS Eyreville A and C cores, Chesapeake Bay impact structure-Postimpact sediments, 444 to $0 \mathrm{~m}$ depth, in Gohn, G.S., Koeberl, Christian, Miller, K.G., and Reimold, W.U., eds., The ICDP-USGS deep drilling project in the Chesapeake Bay impact structure-Results from the Eyreville core holes: Geological Society of America Special Paper 458, p. 91-114.
Eggleston, Jack, and Pope, Jason, 2013, Land subsidence and relative sea-level rise in the southern Chesapeake Bay region: U.S. Geological Survey Circular 1392, 30 p., accessed August 19, 2019, at https://doi.org/10.3133/ cir1392.

Fennema, R.J., and Newton, V.P., 1982, Ground water resources of the Eastern Shore of Virginia: Virginia State Water Control Board Planning Bulletin 332, 74 p.

Hem, J.D., 1985, Study and interpretation of the chemical characteristics of natural water: U.S. Geological Survey Water-Supply Paper 2254, 263 p.

Hobbs, C.H., III, 2004, Geological history of Chesapeake Bay, USA: Quaternary Science Reviews, v. 23, p. 641-661.

Krantz, D.E., Hobbs, C.H., III, and Wikel, G.L., 2016, Atlantic Coast and Inner Shelf, in Bailey, C.M., Sherwood W.C., Eaton, L.S., and Powars, D.S., eds., Geology of Virginia: Martinsville, Virginia, Virginia Museum of Natural History, p. $341-380$.

Masterson, J.P., Pope, J.P., Fienen, M.N., Monti, Jack, Jr., Nardi, M.R., and Finkelstein, J.S., 2016, Documentation of a groundwater flow model developed to assess groundwater availability in the Northern Atlantic Coastal Plain aquifer system from Long Island, New York, to North Carolina: U.S. Geological Survey Scientific Investigations Report 2016-5076, 70 p., accessed August 19, 2019, at https://doi. org/10.3133/sir20165076.

McFarland, E.R., 2010, Groundwater-quality data and regional trends in the Virginia Coastal Plain, 1906-2007: U.S. Geological Survey Professional Paper 1772, 86 p.

McFarland, E.R., 2015, A conceptual framework and monitoring strategy for movement of saltwater in the Coastal Plain aquifer system of Virginia: U.S. Geological Survey Scientific Investigations Report 2015-5117, 30 p.

McFarland, E.R., 2019, Borehole hydrogeologic-unit topsurface altitudes, aquifer hydraulic properties, and groundwater-sample chloride-concentration data from 1906 through 2016 for the Virginia Eastern Shore: U.S. Geological Survey data release, https://doi.org/10.5066/ P9MPE5SD.

McFarland, E.R., and Bruce, T.S., 2005, Distribution, origin, and resource-management implications of ground-water salinity along the western margin of the Chesapeake Bay impact structure in eastern Virginia, in Horton, J.W., Jr., Powars, D.S., and Gohn, G.S., eds., Studies of the Chesapeake Bay impact structure-The USGS-NASA Langely corehole, Hampton, Virginia, and related coreholes and geophysical surveys: U.S. Geological Survey Professional Paper 1688, chap. K, 32 p. 
McFarland, E.R., and Bruce, T.S., 2006, The Virginia Coastal Plain hydrogeologic framework: U.S. Geological Survey Professional Paper 1731, 118 p., 25 pls.

Meng, A.A., III, and Harsh, J.F., 1988, Hydrogeologic framework of the Virginia Coastal Plain: U.S. Geological Survey Professional Paper 1404-C, 82 p.

Mixon, R.B., 1985, Stratigraphic and geomorphic framework of uppermost Cenozoic deposits in the southern Delmarva Peninsula, Virginia and Maryland: U.S. Geological Survey Professional Paper 1067-G, 53 p., 2 pls.

Mixon, R.B., Berquist, C.R., Jr., Newell, W.L., Johnson, G.H., Powars, D.S., Schindler, J.S., and Rader, E.K., 1989, Geologic map and generalized cross sections of the Coastal Plain and adjacent parts of the Piedmont, Virginia: U.S. Geological Survey Miscellaneous Investigations Series Map I-2033, scale 1:250,000.

Nowroozi, A.A., Karst, A.T., and Henderson, P.N., 2003, Paleochannels and water resources of the Eastern Shore of Virginia-A case study by electrical resistivity methods: Southeastern Geology, v. 41, no. 4, p. 177-199.

Oertel, G.F., and Foyle, A.M., 1995, Drainage displacement by sea-level fluctuation at the outer margin of the Chesapeake seaway: Journal of Coastal Research, v. 11, no. 3, p. 583-604.

Powars, D.S., 2011, Middle and late Pleistocene geology of the Eastern Shore of Virginia and relationship to the Chesapeake Bay impact structure with impact debris core display: 41st Virginia Geological Field Conference, Wachapreague, Virginia, October 29-30, 2011, p. 15-35.

Powars, D.S., and Bruce, T.S., 1999, The effects of the Chesapeake Bay impact crater on the geological framework and correlation of hydrogeologic units of the lower York-James Peninsula, Virginia: U.S. Geological Survey Professional Paper 1612, 82 p., 9 pls.

Powars, D.S., Edwards, L.E., Johnson, G.H., and Berquist, C.R., 2016, Geology of the Virginia Coastal Plain-New insights from continuous cores and geophysical surveys, in Bailey, C.M., Sherwood, W.C., Eaton, L.S., and Powars, D.S., eds., Geology of Virginia: Martinsville, Virginia, Virginia Museum of Natural History, p. 193-240.

Prinos, S.T., and Valderrama, Robert, 2016, Collection, processing, and quality assurance of time-series electromagnetic-induction log datasets, 1995-2016, south Florida: U.S. Geological Survey Open-File Report 2016-1194, 70 p.
Richardson, D.L., 1994, Hydrogeology and analysis of the ground-water-flow system of the Eastern Shore, Virginia: U.S. Geological Survey Water-Supply Paper 2401, 108 p., $1 \mathrm{pl}$.

Sanford, W.E., Pope, J.P., and Nelms, D.L., 2009, Simulation of ground-water-level and salinity changes in the Eastern Shore of Virginia: U.S. Geological Survey Scientific Investigations Report 2009-5066, 125 p.

Sinnott, Allen, and Tibbitts, G.C., 1954, Summary of geology and ground-water resources of the Eastern Shore peninsula, Virginia: Virginia Division of Geology Mineral Resources Circular no. 2, 18 p.

Sinnott, Allen, and Tibbitts, G.C., 1955, Records of selected wells on the Eastern Shore peninsula, Virginia: Virginia Division of Geology Mineral Resources Circular no. 3, $39 \mathrm{p}$.

Sinnott, Allen, and Tibbitts, G.C., 1957, Subsurface correlations based on selected well logs from the Eastern Shore peninsula, Virginia: Virginia Division of Mineral Resources Circular no. 6, $11 \mathrm{p}$.

Sinnott, Allen, and Tibbitts, G.C., 1968, Ground-water resources of Accomack and Northampton Counties, Virginia: Virginia Division of Mineral Resources Report 9, 113 p., 4 pls.

U.S. Environmental Protection Agency, 1990, Secondary maximum-contaminant levels (section 143.3 of part 143, National secondary drinking water regulations): U.S. Code of Federal Regulations, Title 40, Parts 100 to 149, revised as of July 1, 1990, p. 696, accessed August 19, 2019, at https:// www.epa.gov/sites/production/files/2015-11/documents/ howeparegulates_cfr-2003-title40-vol20-part143.pdf.

U.S. Geological Survey, 2017, USGS water data for the Nation: U.S. Geological Survey National Water Information System database, accessed March 21, 2017, at https://doi. org/10.5066/F7P55KJN.

Ward. L.W., and Strickland, G.L., 1985, Outline of Tertiary stratigraphy and depositional history of the U.S. Atlantic Coastal Plain, in Poag, C.W., ed., Geologic evolution of the United States Atlantic margin: New York, Van Nostrand Reinhold, p. 87-124. 
Publishing support provided by the

U.S. Geological Survey Science Publishing Network,

West Trenton Publishing Service Center

For more information concerning the research in this report, contact:

Director, Virginia/West Virginia Science Center

U.S. Geological Survey

1730 East Parham Road

Richmond, Virginia 23228

https://www.usgs.gov/centers/va-wv-water 


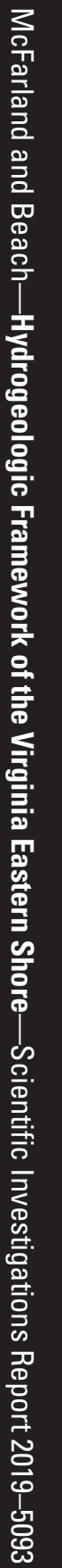

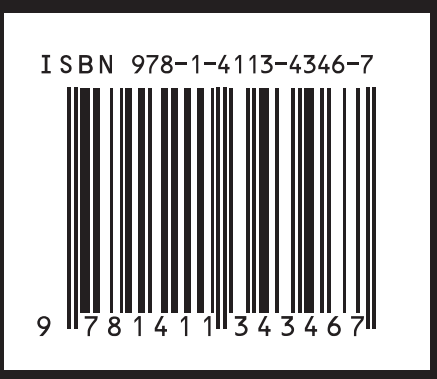

